\title{
41. GEOTECHNICAL PROPERTIES OF SEDIMENTS FROM WALVIS RIDGE, DEEP SEA DRILLING PROJECT, LEG 75, HOLE 532A ${ }^{1}$
}

\author{
Geotechnical Consortium²
}

\begin{abstract}
During Leg 75 of the Deep Sea Drilling Project (DSDP) from the D/V Glomar Challenger, a 200-m deep hole was drilled at Hole 532A on the eastern side of Walvis Ridge at a water depth of $1331 \mathrm{~m}$. Sediment cores were obtained by means of a hydraulic piston corer. All of the cores from this boring were designated for geotechnical studies and were distributed among eight institutions. The results of laboratory studies on these sediment cores were compiled and analyzed. Sediment properties, including physical characteristics, strength, consolidation, and permeability were studied to evaluate changes as a function of depth of burial. It was concluded that the sediment profile to the explored depth of $200 \mathrm{~m}$ at Walvis Ridge consists of approximately $50 \mathrm{~m}$ of foram-nannofossil marl (Subunit 1a) over $64 \mathrm{~m}$ of diatomnannofossil marl (Subunit 1b) over nannofossil marl (Subunit 1c) to the depth explored. All three sediment units appear to be normally consolidated, although some anomalies seem to exist to a depth of $120 \mathrm{~m}$. No distinct differences were found among the sediment properties of the three subunits $(1 \mathrm{a}, 1 \mathrm{~b}$, and $1 \mathrm{c})$ identified at this site.
\end{abstract}

\section{INTRODUCTION}

This chapter describes the results of geotechnical studies on sediments from Hole 532A which were obtained with a hydraulic piston corer from the Walvis Ridge during Leg 75 of the DSDP. Hole 532A was located on the eastern part of Walvis Ridge in a trough with relatively thick sediment fill. A $200-\mathrm{m}$ section was continuously cored; core sections were sealed immediately and stored in an upright position in the cold storage of the ship. They were then shipped to the core storage at LamontDoherty Geological Observatory of Columbia University. The cores were processed by the Geotechnical Consortium at this laboratory, and core sections were distributed among eight institutions (AOML, HSU, LU, OSU, SDSU, TAMU, CU, and URI) for laboratory testing.

The geotechnical investigation included measurement of sediment index and classification properties, strength characteristics, compressibility, and permeability properties. The results of the studies were analyzed and synthesized to prepare this chapter.

\section{INDEX PROPERTIES}

Selected index and classification properties were measured in order to investigate changes in the properties as

\footnotetext{
${ }^{1}$ Hay, W. W., Sibuet, J.-C., et al., Init. Repts. DSDP, 75: Washington (U.S. Govt. Printing Office).

2 The geotechnical consortium for DSDP Leg 75 consisted of Atlantic Oceanographic and Meteorological Laboratory (AOML), Miami, Florida; Humboldt State University (HSU), Areata, California; Lehigh University (LU), Bethlehem, Pennsylvania; Oregon State University (OSU), Corvallis, Oregon; San Diego State University (SDSU), San Diego, California; Texas A\&M University (TAMU), College Station, Texas; University of Colorado (CU), Boulder, Colorado; and University of Rhode Island (URI), Narragansett, Rhode Island.

The following persons from these institutions contributed to this chapter: AOML: Richard H. Bennett, and Gideon Almagor (on leave from Geological Survey of Israel); HSU: Ronald C. Chaney, Michael Meyer, and Ronald Ward; LU: Adrian F. Richards; OSU: George H. Keller; SDSU: Iraj Noorany; TAMU: William R. Bryant and Elliott Taylor; CU: Robert Schiffman, Nam J. Yoo, and Dobroslav Znidarcic (on leave from University of Zagreb, Yugoslavia); URI: Armand J. Silva and William P. Levy.
}

a function of depth of burial and lithologic character. Three lithologic subunits (1a, 1b, and 1c) were identified for Hole 532, which was drilled close to, but to the northwest of, Hole 532A. A description of these lithologic subunits is presented in Table 1. Although the three subunits were recognized on the basis of relative proportions of biogenic components and clay, the sediments were entirely calcareous (11-76\%) and siliceous biogenic pelagic deposits containing variable amounts of terrigenous clay and organic carbon (see site summary, this volume). The absence of major variations in lithology accounts for the lack of any remarkable differences in geotechnical properties of the sediment with depth of burial other than those caused by consolidation processes.

The index and classification tests that were made on selected samples are: wet-bulk density, water content, specific gravity, Atterberg limits, grain size analysis, and calcium carbonate content. A summary of all index/ classification tests on the sediment is presented in Table 2.

\section{Wet-Bulk Density}

Wet-bulk density increases with depth of burial (Fig. 1) with no recognizable relationship to the different subunit lithologies. In the upper $120 \mathrm{~m}$, wet-bulk density varies relatively little, ranging from 1.38 to $1.50 \mathrm{Mg} / \mathrm{m}^{3}$, and shows no notable increase with depth as would usually be expected. Considering the uniformity of the sediment, the lack of a progressive change with depth in this zone must be considered anomalous. Below $120 \mathrm{~m}$ there is a gradual increase in bulk density ( 1.47 to $1.75 \mathrm{Mg} / \mathrm{m}^{3}$ ) to the bottom of the cored interval $(199.5 \mathrm{~m})$, which appears to reflect the expected increase in density as a result of overburden.

The density gradient between the sediment surface and a given depth was calculated using wet-bulk density values and the equation $d=\left(\varrho_{h}-\varrho_{o}\right) / h$, where $\varrho_{h}$ is the wet-bulk density $\left(\mathrm{Mg} / \mathrm{m}^{3}\right)$ at a given depth, $h(\mathrm{~m})$, and 
Table 1. Lithologic units, Site 532.

\begin{tabular}{cccccccc}
\hline Unit & Lithology & Hole & Cores & $\begin{array}{c}\text { Sub-bottom } \\
\text { depth } \\
(\mathrm{m})\end{array}$ & $\begin{array}{c}\text { Thickness } \\
(\mathrm{m})\end{array}$ & Age & $\begin{array}{c}\text { Sedimentation } \\
\text { rate } \\
(\mathrm{m} / \mathrm{m} . \mathrm{y} .)\end{array}$ \\
\hline 1a & $\begin{array}{c}\text { Foram-nannofossil } \\
\text { marl and ooze }\end{array}$ & 532 & $1-12$ & $0-49.5$ & 49.5 & Pleistocene & 41 \\
1b & $\begin{array}{c}\text { Diatom-nannofossil } \\
\text { marl }\end{array}$ & 532 & $12-26$ & $49.5-114.0$ & 64.5 & late Pliocene & 52 \\
1c & $\begin{array}{c}\text { Nannofossil marl } \\
532\end{array}$ & $\begin{array}{l}532 \mathrm{~B} \\
532-61\end{array}$ & $114.0-291.3$ & 117.3 & $\begin{array}{c}\text { late Pliocene- } \\
\text { late Miocene }\end{array}$ & 40 \\
\hline
\end{tabular}

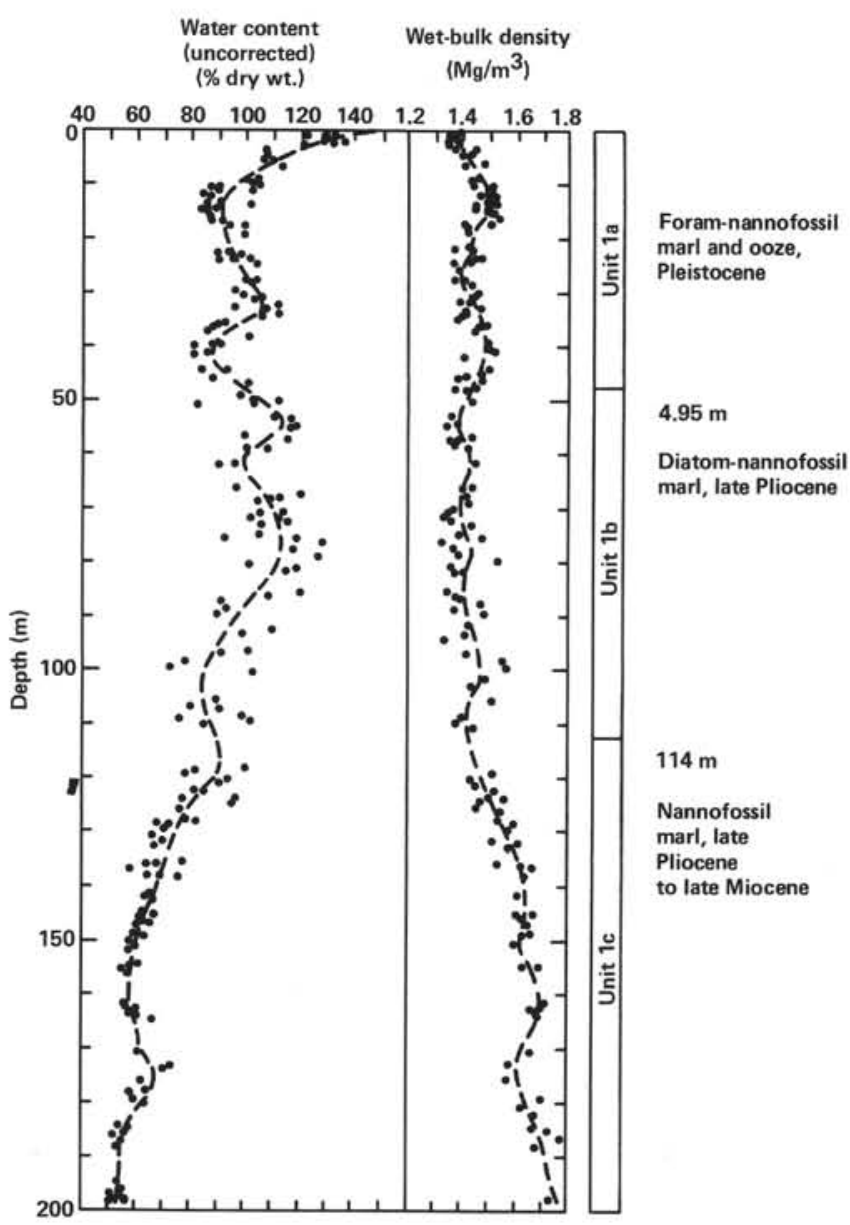

Figure 1. Profile of water contents and wet-bulk density.

$\varrho_{o}$ is the sediment density at the surface. The wet-bulk density gradient is presented in Figure 2 in terms of $\left(\mathrm{Mg} / \mathrm{m}^{3}\right) / \mathrm{m} \times 10^{-4}$.

Based on data available from DSDP, Hamilton (1976) reported for the upper $600 \mathrm{~m}$ of the seafloor distinctive patterns of density gradients for several sediment types. $\mathrm{He}$ found that the density gradient increased with depth for both pelagic clays and radiolarian oozes. For the latter, however, he showed a considerably higher gradient than for the pelagic clays. In the case of calcareous and diatomaceous oozes as well as for terrigenous sediments, Hamilton (1976) found that the density gradients decreased with depth, with the calcareous deposits displaying the greatest decrease in gradient.

Hole 532A shows a pronounced decrease in the density gradient from the surface to $50 \mathrm{~m}$, a decrease some-

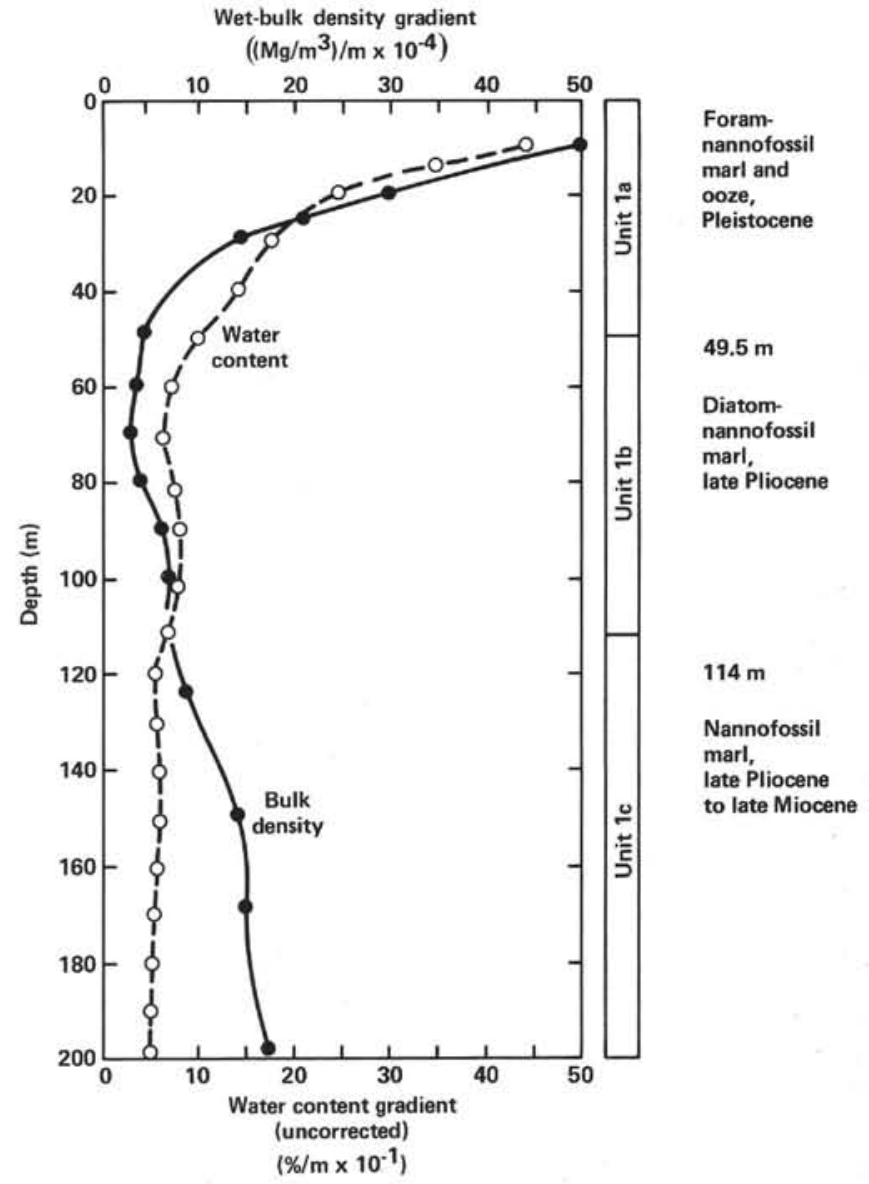

Figure 2. Profile of density and water content gradients.

what similar to what Hamilton had reported in the upper $50 \mathrm{~m}$ for calcareous ooze, but considerably greater. From 50 to $80 \mathrm{~m}$, the gradient is rather small and remains somewhat uniform (Fig. 2). Below $80 \mathrm{~m}$, however, the gradient reverses and increases notably to the bottom of the cored interval $(199.5 \mathrm{~m})$. Such a reversal might possibly be attributed to pronounced changes in the sediment's physical or compositional properties, such as distinct changes in texture and/or cementation or mineralogy. However, in the case of Hole 532A, where the sediment appears to be rather homogeneous, the reason for the observed reversal is not readily apparent. One possible explanation is that during the initial visual inspection of the material, large amounts of gas bubbles were observed at the sediment surface (i.e., between the walls of the coring tube and the sediment) along much of its length. The presence of gas in the sediment, and its 
Table 2. Summary of index properties, Hole 532A.

\begin{tabular}{|c|c|c|c|c|c|c|c|c|c|c|}
\hline & & & & & & & & & & \\
\hline $\begin{array}{l}\text { Core- } \\
\text { Section }\end{array}$ & $\begin{array}{l}\text { Depth } \\
\text { (m) }\end{array}$ & $\left(\mathrm{Mg}^{e} / \mathrm{m}^{3}\right)$ & $\begin{array}{c}w \\
(\%)\end{array}$ & $\begin{array}{l}\bar{w} \\
(\%)\end{array}$ & $\left(\mathrm{Mg}_{\mathrm{ed}}^{\mathrm{ed}} \mathrm{m}^{3}\right)$ & $G_{s}$ & $e$ & $\stackrel{n}{n}(\%)$ & $\underset{(\%)}{L L}$ & $\begin{array}{c}P I \\
(\%)\end{array}$ \\
\hline $1-1$ & 0.03 & 1.32 & 155 & 160 & 0.51 & 2.61 & 4.11 & 80.6 & & \\
\hline $1-1$ & 0.29 & 1.43 & 112 & 116 & 0.66 & & & & & \\
\hline $1-1$ & 0.98 & 1.38 & 139 & 144 & 0.57 & & 3.49 & 78.0 & & \\
\hline $1-1$ & 1.48 & 1.37 & 133 & 138 & 0.58 & & & & & \\
\hline $1-2$ & 1.57 & 1.38 & 123 & 127 & 0.61 & & & & & \\
\hline $1-2$ & 1.70 & 1.38 & 123 & 127 & 0.61 & & & & & \\
\hline $1-2$ & 2.45 & 1.36 & 133 & 138 & 0.57 & & & & & \\
\hline $1-2$ & 2.51 & & 137 & 142 & & & & & 152 & 67 \\
\hline $1-2$ & 2.95 & 1.39 & 122 & 126 & 0.62 & & & & & \\
\hline $1-3$ & 3.07 & 1.36 & 127 & 131 & 0.61 & 2.61 & 3.28 & 76.6 & & \\
\hline $1-3$ & 3.19 & 1.40 & 120 & 124 & 0.63 & & & & & \\
\hline $2-1$ & 3.63 & & & & & & & & & \\
\hline $2-1$ & 3.77 & & & & & & & & & \\
\hline $2-1$ & 4.00 & 1.45 & 108 & 112 & 0.68 & 2.63 & 2.86 & 74.3 & & \\
\hline $\begin{array}{l}2-1 \\
2-1\end{array}$ & $\begin{array}{l}4.13 \\
4.79\end{array}$ & $\begin{array}{l}1.44 \\
1.44\end{array}$ & $\begin{array}{l}102 \\
108\end{array}$ & $\begin{array}{l}106 \\
112\end{array}$ & $\begin{array}{l}0.70 \\
0.68\end{array}$ & & & & & \\
\hline $\begin{array}{l}2-1 \\
2-2\end{array}$ & $\begin{array}{l}4.79 \\
4.98\end{array}$ & 1.44 & 109 & 113 & & & & & & \\
\hline $\begin{array}{l}2-2 \\
2-2\end{array}$ & 5.58 & 1.43 & 108 & 112 & 0.67 & & & & & \\
\hline $2-2$ & 6.19 & 1.43 & 110 & 114 & 0.67 & & & & & \\
\hline $2-2$ & 6.19 & 1.43 & 110 & 114 & 0.67 & & & & & \\
\hline $2-3$ & 6.53 & 1.46 & 96 & 99 & 0.73 & 2.64 & 2.61 & 72.5 & & \\
\hline $2-3$ & 7.00 & 1.42 & 114 & 118 & 0.65 & 2.63 & 3.05 & 75.2 & 104 & 34 \\
\hline $3-2$ & 9.31 & 1.46 & 101 & 104 & 0.72 & 2.64 & 2.67 & 73.0 & & \\
\hline $3-2$ & 9.48 & 1.45 & 105 & 109 & 0.69 & & & & & \\
\hline $3-2$ & 10.35 & 1.45 & 103 & 107 & 0.70 & & & & & \\
\hline $3-2$ & 10.65 & 1.45 & 105 & 109 & 0.69 & & & & & \\
\hline 3-3 & 10.85 & & & & & & & & & \\
\hline $3-3$ & 10.93 & 1.45 & 103 & 107 & 0.70 & & & & & \\
\hline 3-3 & 11.08 & 1.50 & 88 & 91 & 0.79 & 2.66 & 2.37 & 70.2 & & \\
\hline 3-3 & 11.13 & 1.51 & 90 & 93 & 0.78 & & & & & \\
\hline $3-3$ & 11.25 & 1.53 & 83 & 86 & 0.82 & 2.67 & 2.25 & 69.4 & & \\
\hline $3-3$ & 11.97 & 1.50 & 90 & 93 & 0.78 & & 2.48 & 71.2 & & \\
\hline $3-3$ & 12.23 & 1.48 & 85 & 88 & 0.79 & 2.64 & 2.34 & 70.1 & & \\
\hline $4-1$ & 12.46 & 1.54 & 82 & 85 & 0.83 & & & & & \\
\hline $4-1$ & 12.68 & 1.53 & 87 & 90 & 0.81 & & & & & \\
\hline $4-1$ & 13.35 & & & & & & & & & \\
\hline $\begin{array}{l}4-1 \\
4-1\end{array}$ & $\begin{array}{l}13.49 \\
13.57\end{array}$ & 1.50 & 91 & 94 & 0.77 & & & & & \\
\hline $\begin{array}{l}4-1 \\
4-2\end{array}$ & 13.81 & 1.53 & 86 & 89 & 0.81 & & & & & \\
\hline $4-2$ & 13.98 & 1.50 & 96 & 99 & 0.75 & & & & & \\
\hline $4-2$ & 14.35 & 1.46 & 102 & 106 & 0.71 & & & & & \\
\hline $4-2$ & 14.65 & 1.46 & 86 & 89 & 0.77 & 2.68 & 2.48 & 71 & & \\
\hline $4-2$ & 15.18 & 1.50 & 89 & 94 & 0.77 & & & & & \\
\hline $4-2$ & 15.19 & 1.51 & 85 & 88 & 0.80 & & & & & \\
\hline $4-3$ & 15.30 & 1.49 & 86 & 89 & 0.79 & & & & & \\
\hline $4-3$ & 15.91 & 1.52 & 84 & 87 & 0.81 & & & & & \\
\hline $4-3$ & 16.30 & 1.51 & 87 & 90 & 0.83 & 2.67 & 2.20 & 70 & 88 & 41 \\
\hline $4-3$ & 16.51 & 1.51 & 83 & 86 & 0.81 & & & & & \\
\hline $5-1$ & $\begin{array}{l}16.75 \\
16.95\end{array}$ & & & & & & & & & \\
\hline $\begin{array}{l}5-1 \\
5-1\end{array}$ & $\begin{array}{l}16.95 \\
17.30\end{array}$ & 1.39 & 120 & 124 & 0.62 & 2.61 & 3.20 & 76 & & \\
\hline $5-1$ & 17.60 & 1.51 & 92 & 95 & 0.77 & & & & & \\
\hline $5-1$ & 17.76 & 1.55 & 81 & 84 & 0.84 & & & & & \\
\hline $5-2$ & 18.16 & 1.42 & 94 & 91 & 0.74 & & & & & \\
\hline $5-2$ & 18.53 & 1.43 & 100 & 104 & 0.70 & & & & & \\
\hline $5-2$ & 19.31 & 1.43 & 100 & 104 & 0.70 & & & & & \\
\hline $5-2$ & 19.46 & 1.46 & 100 & 104 & 0.72 & & & & & \\
\hline $6-1$ & 21.45 & 1.39 & 124 & 128 & 0.61 & 2.58 & 3.22 & 76 & & \\
\hline $6-1$ & 21.91 & & 109 & 113 & & & & & & \\
\hline $6-1$ & 22.46 & & 118 & 122 & & 2.62 & & & 130 & 71 \\
\hline $6-2$ & 22.85 & & 95 & 98 & & & & & & \\
\hline $6-2$ & 23.03 & 1.43 & 94 & & & & & & & \\
\hline $6-2$ & 23.35 & 1.50 & 90 & 93 & 0.78 & & 2.46 & 71 & & \\
\hline $6-2$ & 23.55 & 1.47 & 98 & 101 & 0.73 & & & & & \\
\hline $6-2$ & 23.87 & 1.43 & 96 & 99 & 0.72 & & & & & \\
\hline $6-2$ & 23.93 & 1.46 & 98 & 101 & 0.73 & & & & & \\
\hline $6-3$ & 24.10 & 1.46 & 97 & 100 & 0.73 & & & & & \\
\hline $6-3$ & 24.59 & 1.44 & 112 & 116 & 0.67 & 2.56 & 2.82 & 74 & & \\
\hline $6-3$ & 24.95 & 1.37 & 144 & 118 & 0.63 & & & & & \\
\hline $7-1$ & 26.48 & 1.39 & 157 & 162 & 0.53 & & 3.82 & 79.3 & & \\
\hline 7.1 & 26.98 & & & & & & & & & \\
\hline 7.2 & 27.12 & 1.32 & & & & & & & & \\
\hline $7-2$ & 27.35 & 1.37 & 119 & 123 & 0.61 & 2.56 & 3.19 & 76 & & \\
\hline $7-2$ & 27.99 & 1.48 & 97 & 100 & 0.74 & & & & 132 & 47 \\
\hline $7-2$ & 28.46 & 1.42 & 104 & 108 & 0.68 & & & & & \\
\hline $7-3$ & 28.55 & 1.45 & 103 & 107 & 0.70 & & & & & \\
\hline $7-3$ & 29.03 & 1.43 & 103 & 107 & 0.69 & & & & & \\
\hline $8-1$ & 30.51 & 1.46 & 97 & 100 & 0.73 & & & & & \\
\hline $8-1$ & 30.79 & 1.45 & 99 & 102 & 0.72 & & & & & \\
\hline $8-1$ & 31.20 & 1.44 & 106 & 110 & 0.69 & & & & & \\
\hline $8-1$ & 31.21 & 1.42 & 105 & 109 & 0.70 & & & & & \\
\hline $8-2$ & 31.51 & 1.44 & 103 & 107 & 0.70 & & & & & \\
\hline $8-2$ & 31.64 & 1.43 & 110 & 114 & 0.67 & & & & & \\
\hline $8-2$ & 32.11 & 1.40 & 123 & 127 & 0.62 & 2.55 & 3.14 & 76 & & \\
\hline $8-2$ & $\begin{array}{l}32.71 \\
33.06\end{array}$ & $\begin{array}{l}1.41 \\
1.47\end{array}$ & 112 & 116 & 0.65 & & & & & \\
\hline $\begin{array}{l}8-3 \\
8-3\end{array}$ & $\begin{array}{l}33.06 \\
33.51\end{array}$ & $\begin{array}{l}1.47 \\
1.42\end{array}$ & $\begin{array}{r}96 \\
108\end{array}$ & $\begin{array}{r}99 \\
112\end{array}$ & $\begin{array}{l}0.74 \\
0.67\end{array}$ & & & & & \\
\hline $\begin{array}{l}8-3 \\
9-1\end{array}$ & $\begin{array}{l}33.51 \\
34.30\end{array}$ & $\begin{array}{l}1.42 \\
1.42\end{array}$ & 108 & 112 & 0.61 & & 2.82 & 73.8 & & \\
\hline $\begin{array}{l}9-1 \\
9-1\end{array}$ & 34.75 & 1.41 & 106 & 110 & 0.67 & & 2.68 & & & \\
\hline $9-1$ & 35.66 & 1.40 & 119 & 123 & 0.63 & & & & & \\
\hline
\end{tabular}


Table 2. (Continued).

\begin{tabular}{|c|c|c|c|c|c|c|c|c|c|c|c|c|}
\hline & & & & & & & & & & & $\begin{array}{r}\text { Grain } \\
\quad(\mathrm{mn} \\
\end{array}$ & $\begin{array}{l}\text { size } \\
\text { m) }\end{array}$ \\
\hline $\begin{array}{l}\text { Core- } \\
\text { Section }\end{array}$ & $\begin{array}{l}\text { Depth } \\
\text { (m) }\end{array}$ & $\left(\mathrm{Mg}^{\mathrm{e}} / \mathrm{m}^{3}\right)$ & $\begin{array}{c}w \\
(\%)\end{array}$ & $\begin{array}{c}\bar{w} \\
(\%)\end{array}$ & $\begin{array}{c}e d \\
\left(\mathrm{Mg} / \mathrm{m}^{3}\right)\end{array}$ & $G_{s}$ & $e$ & $\begin{array}{c}n \\
(\%)\end{array}$ & $\underset{(\%)}{L L}$ & $\begin{array}{c}P I \\
(\%)\end{array}$ & $\begin{array}{l}0.074 \\
\text { (\% pas }\end{array}$ & $\begin{array}{c}0.002 \\
\text { ssing) }\end{array}$ \\
\hline $9-2$ & 35.71 & & 100 & 104 & & & & & & & & \\
\hline $9-2$ & 35.26 & 1.49 & 92 & 95 & 0.76 & & 2.38 & 70.4 & 85 & 31 & 98 & 45 \\
\hline $9-2$ & 36.45 & 1.47 & 90 & 93 & 0.76 & & & & & & & \\
\hline $9-2$ & 36.81 & 1.47 & 88 & 91 & 0.77 & 2.63 & 2.31 & 70.0 & & & & \\
\hline $9-3$ & 37.26 & 1.46 & 95 & 98 & 0.74 & & & & & & & \\
\hline $9-3$ & 37.51 & 1.51 & 86 & 89 & 0.80 & & & & & & 98 & 45 \\
\hline $10-1$ & 40.00 & 1.50 & 90 & 93 & 0.78 & & & & & & & \\
\hline $10-2$ & 40.15 & 1.46 & 87 & 90 & 0.77 & & & & & & & \\
\hline $10-2$ & 40.76 & 1.51 & 81 & 84 & 0.82 & 2.66 & 2.15 & 68.0 & & & & \\
\hline $10-2$ & 41.45 & 1.52 & 84 & 87 & 0.81 & & & & & & & \\
\hline $10-3$ & 41.65 & 1.53 & 81 & 84 & 0.83 & 2.64 & 2.18 & 68.5 & 71 & 26 & & \\
\hline $10-3$ & 42.25 & 1.42 & & & & & & & & & & \\
\hline $11-1$ & 43.40 & & & & & & & & & & & \\
\hline $11-1$ & 43.85 & & 95 & 98 & & & & & & & & \\
\hline $11-1$ & 44.50 & & & & & & & & & & & \\
\hline $11-2$ & 44.60 & 1.50 & & & 0.57 & 2.65 & 3.66 & 79.0 & & & & \\
\hline $11-2$ & 44.85 & 1.50 & 84 & 87 & 0.80 & 2.66 & 2.33 & 69.7 & & & 92 & 51 \\
\hline $11-2$ & 45.50 & 1.48 & 93 & 96 & 0.76 & & & & & & & \\
\hline $11-2$ & 45.95 & 1.42 & 107 & 111 & 0.67 & & & & & & & \\
\hline $11-3$ & 46.05 & 1.40 & 106 & 110 & 0.67 & 2.99 & 2.86 & 74.2 & & & & \\
\hline $11-3$ & 46.35 & 1.48 & 88 & 91 & 0.77 & & & & & & & \\
\hline $12-1$ & 47.95 & 1.45 & 101 & 104 & 0.71 & & & & & & & \\
\hline $12-1$ & 48.35 & 1.38 & 125 & 129 & 0.60 & & 2.61 & 72.3 & & & 97 & 58 \\
\hline $12-1$ & 48.85 & 1.42 & 114 & 118 & 0.65 & & & & & & & \\
\hline $12-2$ & 49.35 & 1.43 & 99 & 102 & 0.71 & & & & & & & \\
\hline $12-2$ & 49.45 & 1.40 & 100 & 104 & 0.69 & & & & & & & ' \\
\hline $12-2$ & 50.10 & 1.44 & 103 & 107 & 0.70 & & 2.74 & 73.3 & & & 97 & 57 \\
\hline $12-2$ & 50.30 & 1.37 & 99 & 102 & 0.68 & 2.60 & 2.82 & 73.9 & & & & \\
\hline $12-3$ & 50.45 & 1.39 & 106 & 110 & 0.66 & & & & & & & \\
\hline $12-3$ & 50.75 & 1.43 & & & & & & & & & & \\
\hline $12-3$ & 51.00 & & 83 & 86 & & & & & & & 97 & 40 \\
\hline $13-2$ & 53.35 & 1.37 & 111 & 115 & 0.64 & & & & & & & \\
\hline $13-2$ & 53.65 & 1.37 & 117 & 121 & 0.62 & & & & & & & \\
\hline $13-2$ & 54.75 & 1.39 & 118 & 122 & 0.63 & 2.60 & 3.12 & 76.0 & & & & \\
\hline $13-3$ & 54.90 & 1.37 & & & & & & & & & & \\
\hline $13-3$ & $\begin{array}{l}55.00 \\
56.57\end{array}$ & 1.35 & 124 & $\begin{array}{l}128 \\
150\end{array}$ & 0.59 & & & & & & & \\
\hline $\begin{array}{l}14-1 \\
14-1\end{array}$ & $\begin{array}{l}56.57 \\
57.00\end{array}$ & 1.44 & $\begin{array}{l}145 \\
100\end{array}$ & $\begin{array}{l}104 \\
104\end{array}$ & 0.71 & & & & & & & \\
\hline $\begin{array}{l}14-1 \\
14-1\end{array}$ & 57.25 & 1.40 & 116 & 120 & 0.64 & 2.69 & 3.20 & 76.3 & 105 & 41 & & \\
\hline $14-1$ & 57.65 & 1.39 & 108 & 112 & 0.66 & & & & & & & \\
\hline $14-2$ & 58.05 & 1.37 & 124 & 128 & 0.60 & 2.54 & 3.23 & 76.4 & & & & \\
\hline $14-2$ & 58.32 & 1.38 & 119 & 123 & 0.62 & 2.62 & 3.22 & 76.4 & & & & \\
\hline $14-2$ & 59.15 & 1.43 & 101 & 104 & 0.70 & & & & & & & \\
\hline $14-3$ & $\begin{array}{l}59.30 \\
59.31\end{array}$ & $\begin{array}{l}1.42 \\
1.37\end{array}$ & 108 & 112 & 0.67 & & & & & & & \\
\hline $\begin{array}{l}14-3 \\
15-1\end{array}$ & $\begin{array}{l}59.31 \\
62.00\end{array}$ & $\begin{array}{l}1.37 \\
1.45\end{array}$ & $\begin{array}{r}108 \\
96\end{array}$ & $\begin{array}{r}112 \\
99\end{array}$ & $\begin{array}{l}0.65 \\
0.73\end{array}$ & & & & & & & \\
\hline $\begin{array}{l}15-1 \\
15-2\end{array}$ & $\begin{array}{l}62.00 \\
62.25\end{array}$ & $\begin{array}{l}1.43 \\
1.49\end{array}$ & $\begin{array}{l}96 \\
91\end{array}$ & $\begin{array}{l}99 \\
94\end{array}$ & 0.77 & & & & & & & \\
\hline $15-2$ & 62.35 & 1.50 & 90 & 93 & 0.78 & 2.63 & 2.37 & 70.4 & & & & \\
\hline $16-1$ & 65.00 & & & & & & & & & & & \\
\hline $16-1$ & 65.70 & & & & & & & & & & & \\
\hline $16-1$ & 66.40 & $\begin{array}{l}1.44 \\
1.46\end{array}$ & 97 & 100 & 0.73 & & & & & & 97 & 54 \\
\hline $\begin{array}{l}16-2 \\
16-2\end{array}$ & $\begin{array}{l}66.60 \\
66.80\end{array}$ & $\begin{array}{l}1.46 \\
1.41\end{array}$ & 110 & 114 & 0.66 & 2.62 & 2.96 & 74.8 & & & & \\
\hline $16-2$ & 67.30 & 1.32 & & & & & & & & & & \\
\hline $16-2$ & 67.65 & 1.38 & 121 & 125 & 0.61 & & & & & & & \\
\hline $16-3$ & 68.25 & 1.42 & 113 & 117 & 0.65 & & & & & & 97 & 55 \\
\hline $16-3$ & 68.55 & 1.41 & 111 & 115 & 0.66 & & & & & & & \\
\hline $16-3$ & 69.10 & 1.43 & 105 & 109 & 0.68 & & & & & & & \\
\hline $17-1$ & $\begin{array}{l}70.40 \\
70.80\end{array}$ & 137 & 132 & 137 & 0.58 & & & & & & & \\
\hline $\begin{array}{l}17-1 \\
17-2\end{array}$ & $\begin{array}{l}70.80 \\
71.25\end{array}$ & $\begin{array}{l}1.37 \\
1.42\end{array}$ & $\begin{array}{l}132 \\
105\end{array}$ & $\begin{array}{l}137 \\
109\end{array}$ & 0.68 & & 2.50 & 71.4 & & & 98 & 39 \\
\hline $17-2$ & 71.45 & 1.36 & 114 & 118 & 0.62 & & & & & & & \\
\hline $17-2$ & 71.85 & 1.35 & 104 & 108 & 0.65 & & & & & & 98 & 39 \\
\hline $17-2$ & 72.30 & 1.36 & 113 & 117 & 0.63 & 2.67 & 3.23 & 76.5 & 126 & 26 & & \\
\hline $17-3$ & 72.60 & 1.40 & 115 & 119 & 0.64 & 2.58 & 3.03 & 75.2 & & & & \\
\hline $17-3$ & 73.20 & 1.44 & 106 & 110 & 0.68 & & & & & & & \\
\hline $18-1$ & 75.00 & 1.40 & & & & & & & & & & \\
\hline $18-2$ & 75.30 & 1.36 & 106 & 110 & 0.65 & & & & & & & \\
\hline $18-2$ & 75.65 & 1.48 & 93 & 96 & 0.76 & & & & & & & \\
\hline $18-2$ & 75.80 & 1.47 & 104 & 108 & 0.71 & & & & & & & \\
\hline $18-2$ & 76.10 & 1.38 & 119 & 123 & 0.62 & 2.54 & 3.09 & 75.7 & & & & \\
\hline $\begin{array}{l}18-2 \\
18-3\end{array}$ & $\begin{array}{l}76.80 \\
76.85\end{array}$ & $\begin{array}{l}1.36 \\
1.33\end{array}$ & $\begin{array}{l}128 \\
136\end{array}$ & $\begin{array}{l}132 \\
141\end{array}$ & $\begin{array}{l}0.59 \\
0.55\end{array}$ & 2.50 & 3.23 & 76.5 & & & & \\
\hline $18-3$ & 76.90 & 1.33 & 129 & 134 & 0.53 & & & & & & & \\
\hline $18-3$ & 77.70 & 1.37 & 118 & 122 & 0.62 & & & & & & & \\
\hline $19-1$ & 78.80 & 1.39 & 127 & 131 & 0.60 & & & & & & 98 & 58 \\
\hline $19-1$ & 78.95 & 1.38 & 131 & 136 & 0.58 & & & & & & & \\
\hline $19-1$ & 79.60 & 1.54 & 82 & 85 & 0.83 & & 2.70 & 73.0 & & & & \\
\hline $19-2$ & 79.70 & & 78 & 81 & & & & & & & & \\
\hline $19-2$ & 80.60 & 1.38 & 102 & 106 & 0.67 & & 2.80 & 73.7 & & & 99 & so \\
\hline $19-2$ & 81.10 & 1.37 & 133 & 138 & 0.58 & & & & & & & \\
\hline $19-3$ & 81.50 & 1.40 & 119 & 123 & 0.63 & & & & & & & \\
\hline $19-3$ & 81.65 & 1.38 & 122 & 126 & 0.61 & 2.56 & 3.20 & 76.1 & & & & \\
\hline $\begin{array}{l}19-3 \\
20-2\end{array}$ & $\begin{array}{l}82.05 \\
85.10\end{array}$ & $\begin{array}{l}1.41 \\
.32\end{array}$ & 116 & 120 & 0.64 & & & & & & & \\
\hline $\begin{array}{l}20-2 \\
20-3\end{array}$ & $\begin{array}{l}85.10 \\
85.65\end{array}$ & $\begin{array}{l}1.32 \\
1.35\end{array}$ & & & & & & & & & & \\
\hline $20-3$ & 86.30 & & 119 & 123 & & 2.56 & & & 118 & 42 & & \\
\hline $20-3$ & 86.45 & 1.38 & 121 & 125 & 0.61 & 2.54 & 3.16 & 76.0 & & & & \\
\hline $20-3$ & 86.57 & & 109 & 113 & & & & & & & & \\
\hline $20-3$ & 86.80 & 1.40 & 120 & 124 & 0.63 & & & & & & & \\
\hline
\end{tabular}


Table 2. (Continued).

\begin{tabular}{|c|c|c|c|c|c|c|c|c|c|}
\hline & & & & & & & & & \\
\hline $\begin{array}{l}\text { Core- } \\
\text { Section }\end{array}$ & $\begin{array}{c}\text { Depth } \\
\text { (m) }\end{array}$ & $\left(\mathrm{Mg}_{\mathrm{g}}^{\mathrm{e}} \mathrm{m}^{3}\right)$ & $\begin{array}{c}w \\
(\%)\end{array}$ & $\begin{array}{c}\bar{w} \\
(\%)\end{array}$ & 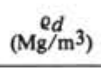 & $G_{s}$ & $e$ & $\begin{array}{c}n \\
(\%)\end{array}$ & $\underset{(\%)}{L L}$ \\
\hline $21-1$ & 87.85 & 1.48 & 92 & 95 & 0.76 & & & & \\
\hline $21-2$ & 88.80 & 1.38 & 93 & 96 & 0.70 & & & & \\
\hline $21-2$ & 89.90 & 1.48 & 90 & 93 & 0.77 & 2.62 & 2.40 & 70.7 & \\
\hline $21-3$ & 90.48 & 1.56 & 78 & 81 & 0.86 & & & & \\
\hline $22-2$ & 92.95 & 1.43 & 110 & 114 & 0.67 & & & & \\
\hline $22-2$ & 93.75 & 1.42 & 99 & 102 & 0.70 & 2.70 & & & 126 \\
\hline $22-2$ & 94.20 & 1.33 & & & & & & & \\
\hline $22-3$ & 94.40 & 1.34 & & & & & & & \\
\hline $22-3$ & 94.85 & 1.40 & 114 & 118 & 0.64 & 2.57 & 3.01 & 75.2 & \\
\hline $23-1$ & 96.32 & & & & & & & & \\
\hline 23-1 & 97.05 & 1.42 & 101 & 104 & 0.70 & & 2.42 & 70.8 & \\
\hline $23-2$ & 97.45 & 1.48 & 91 & 94 & 0.76 & & & & \\
\hline $23-2$ & 98.70 & 1.55 & 77 & 80 & 0.86 & & & & \\
\hline $23-3$ & 98.90 & 1.61 & 65 & 67 & 0.96 & 2.67 & 1.78 & 64.0 & \\
\hline 23-3 & 98.95 & 1.60 & 66 & 68 & 0.95 & 2.67 & 1.81 & 64.4 & \\
\hline 23-3 & 99.80 & 1.56 & 73 & 76 & 0.89 & & & & \\
\hline 24-1 & 100.85 & & & & & & & & \\
\hline $\begin{array}{l}24-1 \\
24-2\end{array}$ & 101.65 & $\begin{array}{l}1.61 \\
1.48\end{array}$ & $\begin{array}{l}76 \\
82\end{array}$ & $\begin{array}{l}79 \\
85\end{array}$ & 0.90 & & 2.60 & 72.2 & \\
\hline $\begin{array}{l}24-2 \\
24-2\end{array}$ & $\begin{array}{l}101.75 \\
103.10\end{array}$ & $\begin{array}{l}1.48 \\
1.44\end{array}$ & $\begin{array}{r}82 \\
105\end{array}$ & $\begin{array}{r}85 \\
109\end{array}$ & $\begin{array}{l}0.80 \\
0.69\end{array}$ & & 2.60 & 72.2 & \\
\hline $24-3$ & 103.25 & 1.40 & 104 & 108 & 0.67 & 2.60 & 2.88 & 74.2 & \\
\hline $25-2$ & 106.60 & 1.51 & 89 & 92 & 0.79 & & & & \\
\hline $25-2$ & 107.25 & 1.52 & 80 & 83 & 0.83 & & & & \\
\hline $25-3$ & 107.60 & & 90 & 93 & & & & & \\
\hline $25-3$ & 108.35 & 1.58 & 70 & 72 & 0.92 & 2.67 & 1.90 & 65.6 & 84 \\
\hline 26-1 & 109.45 & 1.41 & 99 & 102 & 0.70 & & & & \\
\hline $26-1$ & 109.50 & & 76 & 79 & & & & & \\
\hline $26-1$ & 110.05 & 1.39 & 102 & 106 & 0.67 & & & & \\
\hline 26-1 & 110.30 & 1.51 & 85 & 88 & 0.80 & 2.65 & 2.31 & 69.9 & \\
\hline $26-2$ & 111.20 & 1.44 & 102 & 106 & 0.70 & 2.61 & 2.72 & 73.1 & \\
\hline $28-1$ & 118.45 & 1.46 & 100 & 104 & 0.72 & & & & \\
\hline $28-1$ & 119.20 & & 81 & 84 & & & & & \\
\hline $28-2$ & 119.50 & 1.51 & 78 & 81 & 0.83 & & & & \\
\hline $28-2$ & 120.70 & 1.44 & 93 & 96 & 0.73 & & & & \\
\hline $28-3$ & 121.17 & 1.48 & 91 & 94 & 0.76 & 2.60 & 2.42 & 70.8 & \\
\hline 28-3 & $\begin{array}{l}121.80 \\
122.50\end{array}$ & 1.44 & $\begin{array}{r}102 \\
91\end{array}$ & & 0.70 & & & & \\
\hline $29-1$ & $\begin{array}{l}122.50 \\
123.03\end{array}$ & 1.51 & $\begin{array}{l}91 \\
84\end{array}$ & $\begin{array}{l}94 \\
87\end{array}$ & 0.81 & & & & \\
\hline $\begin{array}{l}29-1 \\
29-1\end{array}$ & $\begin{array}{l}123.03 \\
123.65\end{array}$ & 1.54 & 81 & 84 & 0.84 & & & & \\
\hline $29-2$ & 123.75 & 1.50 & 84 & 87 & 0.80 & & & & \\
\hline $29-2$ & 124.35 & 1.55 & 77 & 80 & 0.86 & & & & \\
\hline $29-2$ & 124.55 & & 96 & 100 & & 2.62 & & & 95 \\
\hline $29-2$ & 124.80 & 1.47 & 95 & 98 & 0.74 & 2.61 & 2.52 & 71.8 & \\
\hline $29-3$ & 125.55 & 1.46 & 98 & 101 & 0.73 & 2.68 & 2.67 & 72.8 & \\
\hline $30-1$ & 126.55 & 1.54 & 76 & 79 & 0.86 & & & & \\
\hline $30-1$ & 128.05 & 1.53 & 78 & 81 & 0.84 & & 2.00 & 66.7 & \\
\hline $30-2$ & 128.15 & 1.50 & & & & & & & \\
\hline $30-2$ & 128.60 & & 82 & 85 & & & & & \\
\hline $30-2$ & 129.05 & 1.59 & 68 & 70 & 0.94 & & & & \\
\hline $30-2$ & 129.52 & 1.58 & 71 & 73 & 0.91 & & & & \\
\hline $30-3$ & 129.60 & 1.58 & 70 & 72 & 0.92 & 2.66 & 1.89 & 65.4 & \\
\hline $30-3$ & 129.75 & 1.55 & 76 & 79 & 0.87 & 2.65 & 2.04 & 67.3 & \\
\hline $31-1$ & 131.52 & & 66 & 68 & & & & & \\
\hline $31-1$ & 131.80 & 1.51 & 82 & 85 & 0.82 & & & & \\
\hline $31-1$ & 131.83 & 1.64 & 64 & 66 & 0.98 & & & & \\
\hline $31-1$ & 132.45 & 1.61 & 69 & 71 & 0.94 & & & & \\
\hline $31-2$ & 132.62 & 1.60 & 67 & 69 & 0.95 & 2.67 & 1.81 & 64.4 & \\
\hline $31-2$ & 132.80 & 1.58 & 69 & 71 & 0.92 & 2.69 & 1.92 & 65.9 & \\
\hline $32-1$ & 135.82 & 1.53 & 77 & 80 & 0.85 & & & & \\
\hline $32-1$ & $\begin{array}{l}136.20 \\
136.87\end{array}$ & 1.62 & $\begin{array}{l}67 \\
64\end{array}$ & $\begin{array}{l}69 \\
66\end{array}$ & 0.96 & & & & \\
\hline $\begin{array}{l}32-1 \\
32-2\end{array}$ & $\begin{array}{l}136.87 \\
136.95\end{array}$ & 1.66 & 58 & $\begin{array}{l}00 \\
60\end{array}$ & 1.03 & 2.69 & 1.61 & 61.7 & \\
\hline $\begin{array}{l}32-2 \\
32-2\end{array}$ & 138.10 & 1.63 & 64 & 66 & 0.98 & & & & \\
\hline $32-3$ & 138.47 & 1.52 & 95 & 98 & 0.77 & 2.62 & 2.40 & 70.7 & \\
\hline $32-3$ & 138.70 & 1.55 & 75 & 78 & 0.87 & 2.66 & 2.06 & 67.2 & \\
\hline $33-1$ & 141.20 & & & & & & & & \\
\hline $33-2$ & 142.05 & 1.60 & 67 & 69 & 0.95 & 2.63 & 1.76 & 64.0 & \\
\hline $33-2$ & 142.75 & 1.60 & 65 & 67 & 0.96 & 2.63 & 1.73 & 63.4 & \\
\hline $33-3$ & 143.02 & 1.62 & 64 & 66 & 0.98 & 2.67 & 1.72 & 63.4 & \\
\hline $34-1$ & 144.20 & 1.64 & 61 & 63 & 1.00 & 2.68 & 1.68 & 62.7 & \\
\hline $34-1$ & 145.35 & 1.66 & 62 & 64 & 1.01 & & 1.63 & 62.0 & \\
\hline $34-2$ & 145.75 & 1.61 & 66 & 68 & 0.96 & & & & \\
\hline $34-2$ & 146.45 & 1.62 & 62 & 64 & 0.98 & & & & \\
\hline $34-2$ & 146.62 & & 62 & 64 & & & & & \\
\hline $34-2$ & 147.17 & 1.62 & 64 & 66 & 0.98 & & & & \\
\hline $34-3$ & 147.40 & 1.64 & 61 & 63 & 1.00 & & & & \\
\hline $34-3$ & 147.62 & 1.60 & 65 & 67 & 0.96 & 2.64 & 1.75 & 63.6 & \\
\hline $35-1$ & 148.90 & 1.65 & 60 & 62 & 1.02 & & & & \\
\hline $35-1$ & 149.10 & 1.63 & 59 & 61 & 1.01 & & & & \\
\hline $35-2$ & 149.95 & & 62 & 64 & & & & & \\
\hline $35-2$ & 150.85 & 1.60 & 58 & 60 & 1.00 & & & & \\
\hline $35-3$ & 151.70 & 1.54 & 59 & 61 & 0.96 & 2.66 & 1.77 & 63.9 & \\
\hline $35-3$ & 152.20 & 1.66 & 58 & 60 & 1.04 & 2.67 & 1.56 & 61.2 & \\
\hline $36-1$ & 154.00 & 1.64 & 59 & 61 & 1.02 & & & & \\
\hline $36-2$ & 154.80 & 1.63 & 60 & 62 & 1.01 & & & & \\
\hline $36-2$ & 155.25 & 1.68 & 57 & 59 & 1.06 & & 1.45 & 59.2 & 66 \\
\hline $36-3$ & 155.62 & 1.68 & 55 & 57 & 1.07 & 2.68 & 1.50 & 60.2 & \\
\hline $36-3$ & 156.10 & 1.68 & 56 & 58 & 1.06 & 2.72 & 1.57 & 61.0 & \\
\hline $36-3$ & 156.57 & & 57 & 59 & & & & & \\
\hline $38-1$ & 161.95 & 1.70 & 57 & 59 & 1.07 & & 1.57 & 61.1 & \\
\hline
\end{tabular}


Table 2. (Continued).

\begin{tabular}{|c|c|c|c|c|c|c|c|c|c|c|c|c|c|}
\hline \multirow[b]{2}{*}{$\begin{array}{l}\text { Core- } \\
\text { Section }\end{array}$} & \multirow[b]{2}{*}{$\begin{array}{l}\text { Depth } \\
\text { (m) }\end{array}$} & \multirow[b]{2}{*}{$\left(\mathrm{Mg}_{\mathrm{g}}^{\mathrm{e}} \mathrm{m}^{3}\right)$} & \multirow[b]{2}{*}{$\begin{array}{c}w \\
(\%)\end{array}$} & \multirow[b]{2}{*}{$\begin{array}{c}\bar{w} \\
(\%)\end{array}$} & \multirow[b]{2}{*}{$\left(\mathrm{Mg}_{\mathrm{g}}^{\mathrm{ed}} \mathrm{m}^{3}\right)$} & \multirow[b]{2}{*}{$G_{s}$} & \multirow[b]{2}{*}{$e$} & \multirow[b]{2}{*}{$\begin{array}{c}n \\
(\%)\end{array}$} & \multirow[b]{2}{*}{$\begin{array}{l}\angle L \\
(\%)\end{array}$} & \multirow[b]{2}{*}{$\begin{array}{c}P I \\
(\%)\end{array}$} & \multicolumn{2}{|c|}{$\begin{array}{c}\text { Grain size } \\
(\mathrm{mm})\end{array}$} & \multirow[b]{2}{*}{$\underset{(\%)}{\mathrm{CaCO}_{3}}$} \\
\hline & & & & & & & & & & & $\begin{array}{l}0.074 \\
(\% \text { pas }\end{array}$ & $\begin{array}{l}0.002 \\
\text { ssing) }\end{array}$ & \\
\hline $38-1$ & 162.35 & & 56 & 58 & & & & & & & & & \\
\hline $38-2$ & 162.90 & 1.69 & 56 & 58 & 1.07 & & & & & & & & \\
\hline $38-2$ & 163.00 & 1.66 & 59 & 61 & 1.03 & & & & & & & & \\
\hline $38-2$ & 163.37 & 1.67 & 58 & 60 & 1.04 & & & & & & & & \\
\hline $38-2$ & 163.65 & 1.67 & 57 & 59 & 1.05 & & & & & & & & 53.0 \\
\hline $38-3$ & 164.02 & 1.67 & 57 & 59 & 1.05 & 2.69 & 1.56 & 61.0 & & & & & \\
\hline $38-3$ & 164.45 & 1.68 & 60 & 62 & 1.04 & 2.58 & 1.48 & 59.7 & & & & & \\
\hline $38-3$ & 165.02 & & 65 & 67 & & & & & & & & & \\
\hline $40-2$ & 170.75 & 1.65 & 61 & 63 & 1.01 & 2.67 & 1.64 & 62.2 & & & 99 & 70 & 34.9 \\
\hline $40-2$ & 170.80 & 1.65 & 60 & 62 & 1.02 & 2.70 & 1.64 & 62.4 & & & & & \\
\hline $40-3$ & 171.60 & & 63 & 65 & & & & & & & & & 53.0 \\
\hline $41-1$ & 173.45 & 1.57 & 72 & 74 & 0.90 & & & & & & & & \\
\hline $41-1$ & $\begin{array}{l}173.60 \\
\end{array}$ & & 80 & 83 & & & & & & & & & \\
\hline $41-1$ & 174.17 & & 70 & 72 & & & & & & & & & \\
\hline $41-2$ & 174.40 & 1.59 & 69 & 71 & 0.93 & 2.66 & 1.86 & 65.0 & & & & & \\
\hline $\begin{array}{l}41-2 \\
41-2\end{array}$ & 175.70 & 1.56 & 67 & 69 & 0.92 & 2.64 & 1.86 & 65.3 & 85 & 35 & & & \\
\hline $41-3$ & 175.90 & & 65 & 67 & & & & & & & & & 46.0 \\
\hline $\begin{array}{l}41-3 \\
41-3\end{array}$ & $\begin{array}{l}176.05 \\
\end{array}$ & & 62 & 64 & & & & & & & & & \\
\hline $42-1$ & 178.25 & 1.62 & 63 & 65 & 0.98 & & & & & & & & \\
\hline $42-2$ & 178.35 & 1.60 & 61 & 63 & 0.98 & & & & & & & & \\
\hline $42-2$ & 179.05 & 1.63 & 58 & 60 & 1.02 & 2.69 & 1.64 & 62.0 & & & & & 35.0 \\
\hline $42-2$ & 179.15 & 1.63 & 55 & 57 & 1.04 & & & & & & & & \\
\hline $42-2$ & $\begin{array}{l}179.60 \\
\end{array}$ & 1.68 & 59 & 61 & 1.04 & 2.66 & 1.55 & 61.1 & & & & & \\
\hline $42-3$ & 179.80 & 1.68 & 55 & 57 & $\begin{array}{l}1.07 \\
\end{array}$ & 2.70 & 1.52 & 60.4 & & & & & \\
\hline $42-3$ & 180.85 & 1.62 & 63 & 65 & 0.98 & & & & & & & & \\
\hline $44-1$ & 184.90 & 1.66 & 56 & 58 & 1.05 & & & & & & & & \\
\hline $44-1$ & 185.15 & 1.71 & 54 & 56 & 1.10 & & 1.37 & 57.9 & & & & & 62.9 \\
\hline $44-2$ & 185.90 & 1.68 & 55 & 57 & 1.07 & & & & & & & & 53.0 \\
\hline $44-2$ & 186.40 & 1.69 & 52 & 54 & 1.10 & & & & & & 98 & 65 & \\
\hline $44-2$ & 186.75 & 1.76 & 47 & 49 & 1.18 & & & & & & & & \\
\hline $44-2$ & 187.15 & 1.77 & 46 & 48 & 1.20 & 2.73 & 1.28 & 56.0 & & & & & \\
\hline $44-3$ & 187.50 & 1.69 & 54 & 56 & 1.08 & 2.69 & 1.49 & 59.9 & & & & & \\
\hline $44-3$ & 187.85 & 1.67 & 54 & 56 & 1.07 & & & & & & 98 & 65 & \\
\hline $47-1$ & 195.20 & 1.69 & 53 & 55 & 1.09 & 2.67 & 1.45 & 59.0 & & & & & \\
\hline $47-1$ & 196.55 & $\begin{array}{l}1.69 \\
\end{array}$ & 54 & 56 & 1.08 & 2.70 & 1.50 & 60.0 & & & & & \\
\hline $47-2$ & 196.72 & 1.40 & 120 & 124 & 0.63 & 2.68 & 3.25 & 76.6 & & & 100 & 65 & \\
\hline $47-2$ & 197.28 & $\begin{array}{l}1.69 \\
\text { S }\end{array}$ & 54 & 56 & 1.08 & 2.69 & 1.49 & 59.8 & & & 99 & 74 & 60.1 \\
\hline 47.2 & 197.65 & 1.72 & 55 & 57 & 1.10 & 2.76 & 1.50 & 60.4 & 83 & 43 & & & 59.0 \\
\hline $47-2$ & 198.12 & & 53 & 55 & & & & & & & & & \\
\hline $47-3$ & 198.20 & 1.72 & 51 & 53 & 1.12 & 2.70 & 1.41 & 58.5 & & & & & \\
\hline $47-3$ & $\begin{array}{l}198.65 \\
\end{array}$ & 1.75 & 50 & 52 & 1.15 & 2.70 & 1.35 & 57.4 & & & 99 & 72 & 54.0 \\
\hline
\end{tabular}

release upon sampling, undoubtedly altered the density characteristics of the sediment to some degree. It might be speculated that the gas content varied in the sediment and thus was not uniform in its effect on the bulk density throughout the sampled interval. Disturbance of the sediment to varying degrees during sampling may also be reflected in these data.

The porosity follows inversely with wet-bulk density and displays a rather uniform decrease of $8.6 \%$ per $100 \mathrm{~m}$ depth (Fig. 3). Again, no significant differences are noted in porosity as a function of sediment (subunit) type. The rate of decrease in porosity with depth is similar to relationships shown by Bryant et al. (1981) for sediments having $65-100 \% \mathrm{CaCO}_{3}$, except that sediment from Hole 532A has somewhat higher initial porosities than those reported by Bryant et al. (1981).

Figure 3 also shows variations of void ratio with depth. The void ratio decreases from a high of 4.05 in the upper meter to 1.35 at $198 \mathrm{~m}$ below the mudline.

\section{Water Content}

The variation of water content (soluble salt content, not corrected) with depth is presented in Table 2 and summarized in Figure 1. All values of water content presented in this chapter are uncorrected values unless otherwise specified. A review of Figure 1 shows that the most significant change in water content occurs in the 0-15 m interval, where it decreases from 155 to $90 \%$. In the interval from 15 to $90 \mathrm{~m}$, there is relatively little change; a relatively minor reduction in water content occurs in the 90 to $120 \mathrm{~m}$ interval. Considering that the sediment is rather heterogeneous throughout the upper $120 \mathrm{~m}$ (Fig. 4) (being composed mainly of varying proportions of silt and clay-size material, with carbonate contents of 40 to $50 \%$, organic carbon contents of 2 to $6 \%$, and nannofossils composing a significant fraction of the material), the presence of a relatively constant water content with depth in this interval is considered anomalous. Below $120 \mathrm{~m}$ there is a gradual decrease in water content to the bottom of the core $(199.5 \mathrm{~m})$ as would generally be expected as a result of increase in depth (Fig. 1).

In addition to the uncorrected water contents, values of water contents corrected for a soluble salt content of $35 \mathrm{ppt}$ using Equation 1 (Noorany, 1982) are present in Table 2.

$$
\bar{w}=\frac{W_{w}}{W_{s}}(1+r),
$$

where $W_{w}=$ mass of water $(\mathrm{g}), W_{s}=$ mass of dry soil, and $r=$ pore-water salinity (typical value, 0.035 ). 


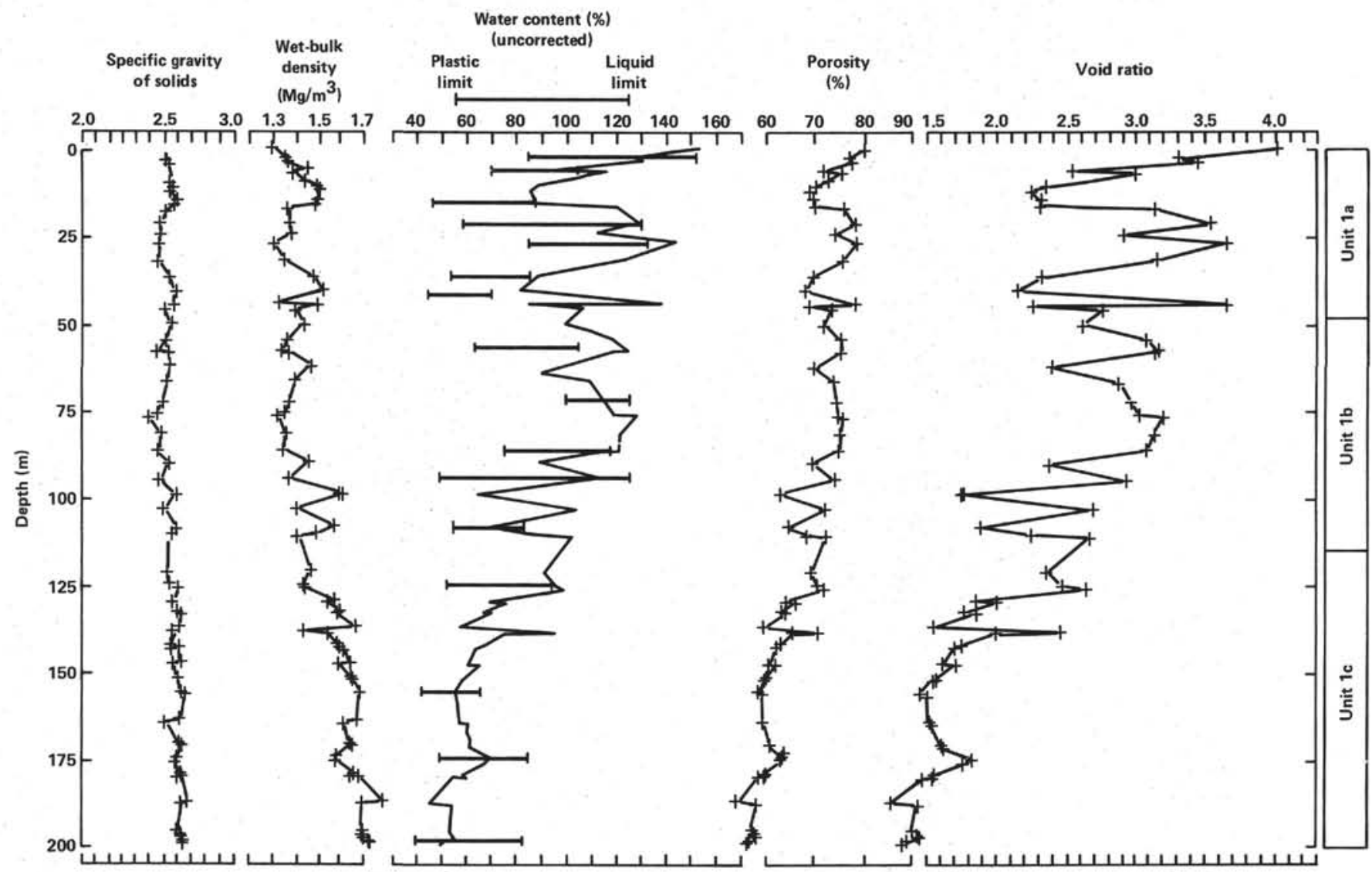

Figure 3. Variation of index properties with depth.

\section{Specific Gravity}

The specific gravity of the solids is generally uniform with depth (Fig. 3 and Table 2). The average value of the specific gravity is $\mathbf{2 . 6 4}$ for the entire core, and values range from 2.49 (Subunit 1b) to 2.73 (Subunit 1c). Specific gravity tests were conducted using the pycnometer method.

\section{Atterberg Limits}

The variation of the liquid and plastic limits with depth along with the natural water content are plotted in Figure 3 and summarized in Table 2. A review of Figure 3 shows that the liquid and plastic limits are rather variable ( $L L=66$ to $152 \% ; P L=40$ to $100 \%)$ and show no consistent relationship to sediment (subunit) type. Furthermore, the natural water contents are frequently higher than the liquid limits in Subunits $1 \mathrm{a}$ and $1 \mathrm{~b}$ but lower than the liquid limit in Subunit 1c.

\section{Grain Size Distribution}

The variation of clay, silt, and sand size particles with depth is presented in Figure 4. The ASTM standard was used for various grain sizes: sand size is larger than $0.074 \mathrm{~mm}$ (U.S. standard sieve No. 200); silt size is finer than $0.074 \mathrm{~mm}$ and larger than $0.002 \mathrm{~mm}$; clay size is finer than $0.002 \mathrm{~mm}$.

A review of Figure 4 shows that clay and silt size material constitute the major portion of the sediment, where clay size material increases with depth in the section from roughly $25 \%$ near the surface to $70 \%$ at $200 \mathrm{~m}$. Sand size material forms a surprisingly high portion of sediment near the surface (up to $35 \%$ ) but decreases quickly below $36 \mathrm{~m}$, staying near $1-2 \%$ of the total. Silt also constitutes as significant a component as clay, with three silt rich lenses $(>55 \%)$ occurring at 19,50 , and $71 \mathrm{~m}$ below the mudline. Grain size distribution tests were done using sieve analysis for the coarse fraction and the pipette and hydrometer methods for silts and clays.

\section{Calcium Carbonate Content}

The variation of calcium carbonate $\left(\mathrm{CaCO}_{3}\right)$ content with depth is presented in Figure 5. The percentage of $\mathrm{CaCO}_{3}$ in this sediment ranges from 11 to $76 \%$. The percent of $\mathrm{CaCO}_{3}$ was obtained using either the Scheibler method (Bouma, 1969) or the "Karbonate Bombe" method (Müller and Gastner, 1971).

\section{STRENGTH PROPERTIES}

The shear strength behavior of sediments is usually very susceptible to alteration of the sediment fabric, and it is therefore important to minimize disturbance resulting from sampling. The hydraulic piston corer provides good quality samples for studying strength and stressstrain properties to considerable depths in the sediment column. The variation of undrained shear strength with depth was measured by means of laboratory vane shear, and unconsolidated-undrained triaxial compression tests. The effective stress parameters on selected samples were 


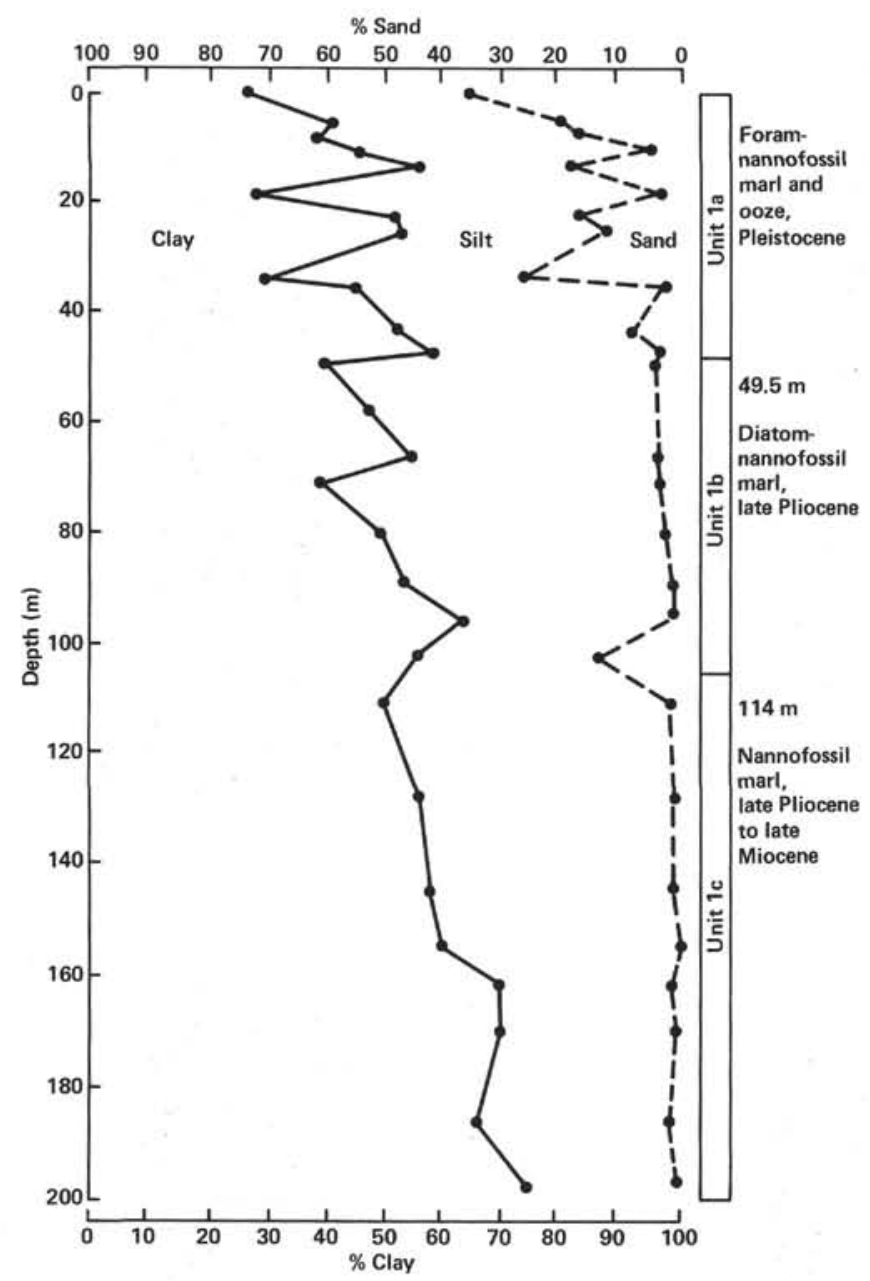

Figure 4. Gradation profile.

determined from isotropically consolidated-undrained triaxial compression and from consolidated-drained direct shear tests.

\section{Vane Shear Strength}

Approximately 200 measurements of peak undrained shear strength $s_{u}$ were made during processing of the sediment cores using motorized laboratory vane apparatus. Another $\mathbf{4 0}$ measurements were made at four separate laboratories (HSU, URI, SDSU, and TAMU). The results of all the vane measurements are plotted in Figure 6 . The mean values of peak shear strength were averaged every $5 \mathrm{~m}$ and plotted in Figure 7 . Vane rotation rates varied between the four vane devices used in this study from $9 \% \mathrm{~min}$. to $79^{\circ} / \mathrm{min}$. For remolded calcareous ooze, Monney (1974) found the average change in shear strength from about $15^{\circ}$ to $90^{\circ} / \mathrm{min}$. rotation to be only about $0.6 \%$, whereas the variation between vane results in this study was much more than this (Fig. 6) and might be mostly caused by sample disturbance.

\section{Unconsolidated-Undrained Triaxial Compression Tests}

Unconsolidated-undrained triaxial compression tests were performed at HSU and SDSU in accordance with the ASTM standard procedure D2850-70. A summary

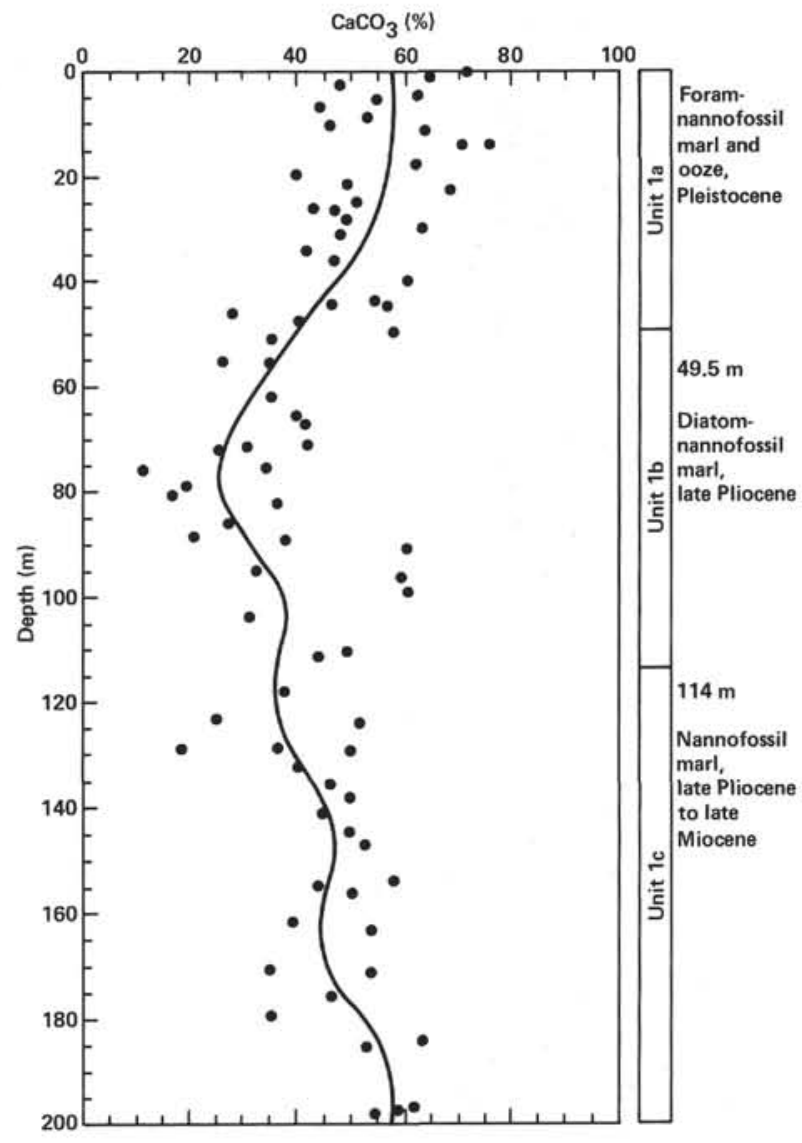

Figure 5. Calcium carbonate content.

of the results appear in Table 3 . Figure 8 presents typical stress-strain data for the UU test series.

\section{Isotropically Consolidated Undrained Triaxial Tests}

Two series of isotropically consolidated-undrained triaxial tests (CIU) with pore pressure measurements were conducted at AOML with procedures described by Bishop and Henkel (1957). All specimens were backpressure saturated and isotropically consolidated under pressures well above the computed in situ effective overburden pressures. The samples were then brought to failure by increasing the vertical stress.

The results of the two series of tests are summarized in Figures 9 and 10. The angles of friction for effective stresses $\phi^{\prime}$ are $38^{\circ}$ and $39^{\circ}$, and the angles of friction for total stresses $\phi_{\mathrm{cu}}$ are $18^{\circ}$ and $22^{\circ}$ for core Samples 532A-1-1, 100-125 cm and $21-2,45-70 \mathrm{~cm}$, respectively. Shipboard summaries record that the sediments are highly calcareous (34-70\% carbonate content, $2-6 \%$ organic carbon content), and high angles of internal friction are indeed expected for these sediments.

The pore pressure coefficient, $A$, at failure ranged from 0.66 to 0.89 . These values are typical of normally consolidated clays (Skempton, 1954).

\section{Direct Shear Tests}

Two series of consolidated drained direct shear tests were conducted at AOML, using ASTM procedure 


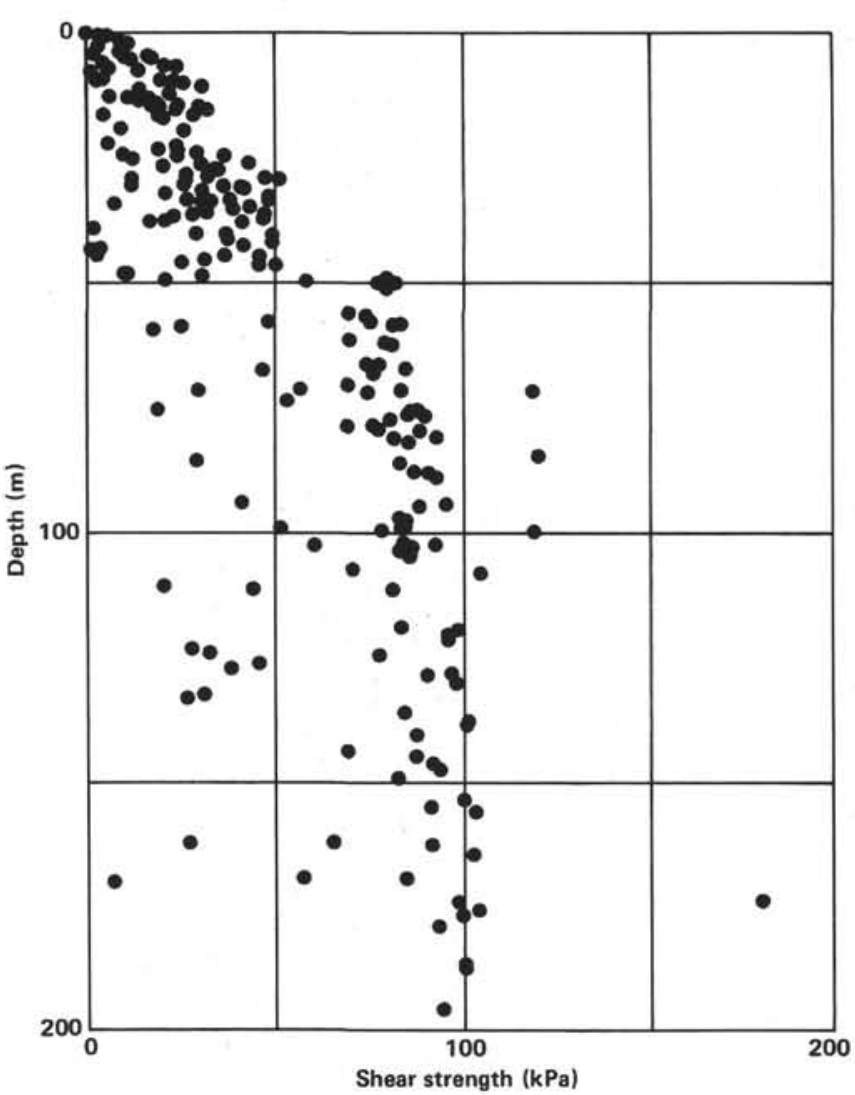

Figure 6. Measured vane shear data.

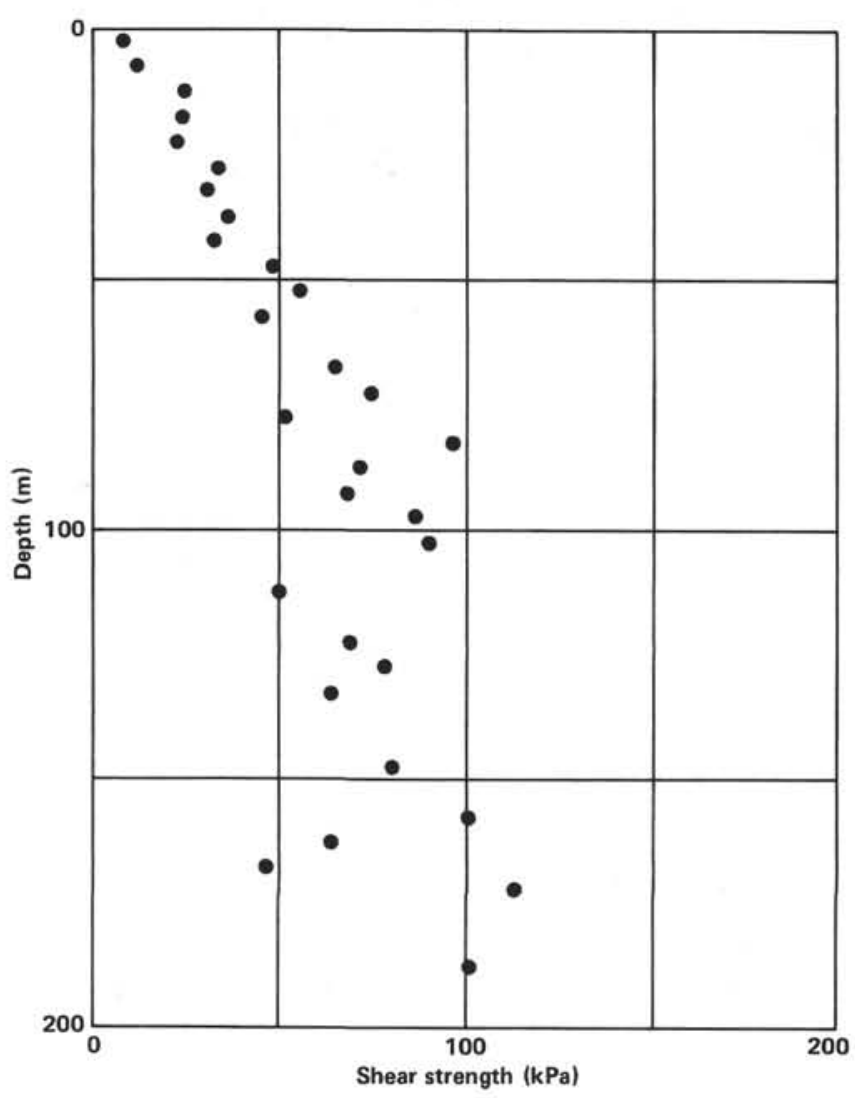

Figure 7. Averaged vane shear data.
Table 3. Summary of UU triaxial test data.

\begin{tabular}{|c|c|c|c|c|}
\hline $\begin{array}{l}\text { Core- } \\
\text { Section }\end{array}$ & $\begin{array}{l}\text { Depth } \\
\text { (m) }\end{array}$ & $\begin{array}{c}\text { Water } \\
\text { content } \\
(\%)\end{array}$ & $\begin{array}{c}\text { Axial } \\
\text { strain } \\
\text { at failure } \\
(\%)\end{array}$ & $\begin{array}{l}\text { Undrained } \\
\text { shear strength } \\
\text { at failure } \\
1 / 2\left(\sigma_{1}-\sigma_{3}\right) \\
(\mathrm{kPa})\end{array}$ \\
\hline $2-2$ & 6.4 & 102 & 9 & 16.6 \\
\hline $4-1$ & 13.7 & 107 & 9 & 26.9 \\
\hline $5-2$ & 19.6 & 94 & 7 & 32.8 \\
\hline $8-2$ & 32.8 & 103 & 9 & 37.3 \\
\hline $24-1$ & 101 & 77 & 8 & 116 \\
\hline $28-1$ & 120 & 85 & 7 & 122 \\
\hline $32-1$ & 137 & 58 & 9 & 151 \\
\hline $38-3$ & 159 & 61 & 9 & 223 \\
\hline
\end{tabular}

D3080-72. The specimens in each series were consolidated to one, two, and four times their computed in situ effective overburden pressures. They were then sheared at a slow rate $\left(5 \times 10^{-4} \mathrm{~cm} / \mathrm{min}\right.$. $)$ to allow complete drainage.

The results of the direct shear tests are summarized in Figures 11 and 12. The effective angles of internal friction were determined; $\phi_{d}=34^{\circ}$ for Sample 6-3, 15-35 $\mathrm{cm}$ and $\phi_{d}=30^{\circ}$ for Sample 19-3, 86-105 cm.

\section{CONSOLIDATION AND PERMEABILITY PROPERTIES}

The character of sediment changes throughout time as a result of physical and chemical processes occurring in the sediment column. These processes significantly alter the nature of the originally deposited material as the sediment is buried. Diagenetic changes within the sediment column modify the individual particles and their interactions, changing the sediment from a loosely bound structure to what may ultimately become a solidified rock. The process resulting in the transformation of an argillaceous sediment from its initial soft clay structure to mudstones or shales is defined as consolidation (Skempton, 1970). Consolidation results in a decrease of void space within the sedimentary mass, with associated increases in bulk density and strength. Simulation of the natural reduction of void space for a sediment with increased overburden or stress is accomplished in the laboratory through use of an oedometer and is denoted as consolidation testing. The term consolidation is applied loosely here since this test is simply a study of sediment compression under applied normal stress and cannot account for time-related changes such as interparticle bonding, cementation, or dissolution or alteration of minerals, nor can it fully duplicate the stress conditions or other factors that form part of this process in situ.

Numerous consolidation/permeability tests have been performed on sediments retrieved by the DSDP (Trabant, 1972; Lee, 1973; Lee, et al., 1973; Trabant et al., 1975, Shephard and Bryant, 1980; Shephard, 1981; Shephard et al., 1982). In this study, a total of 51 consolidation tests were performed, yielding a thorough coverage of the consolidation characteristics and permeabilities for the sediment profile. 

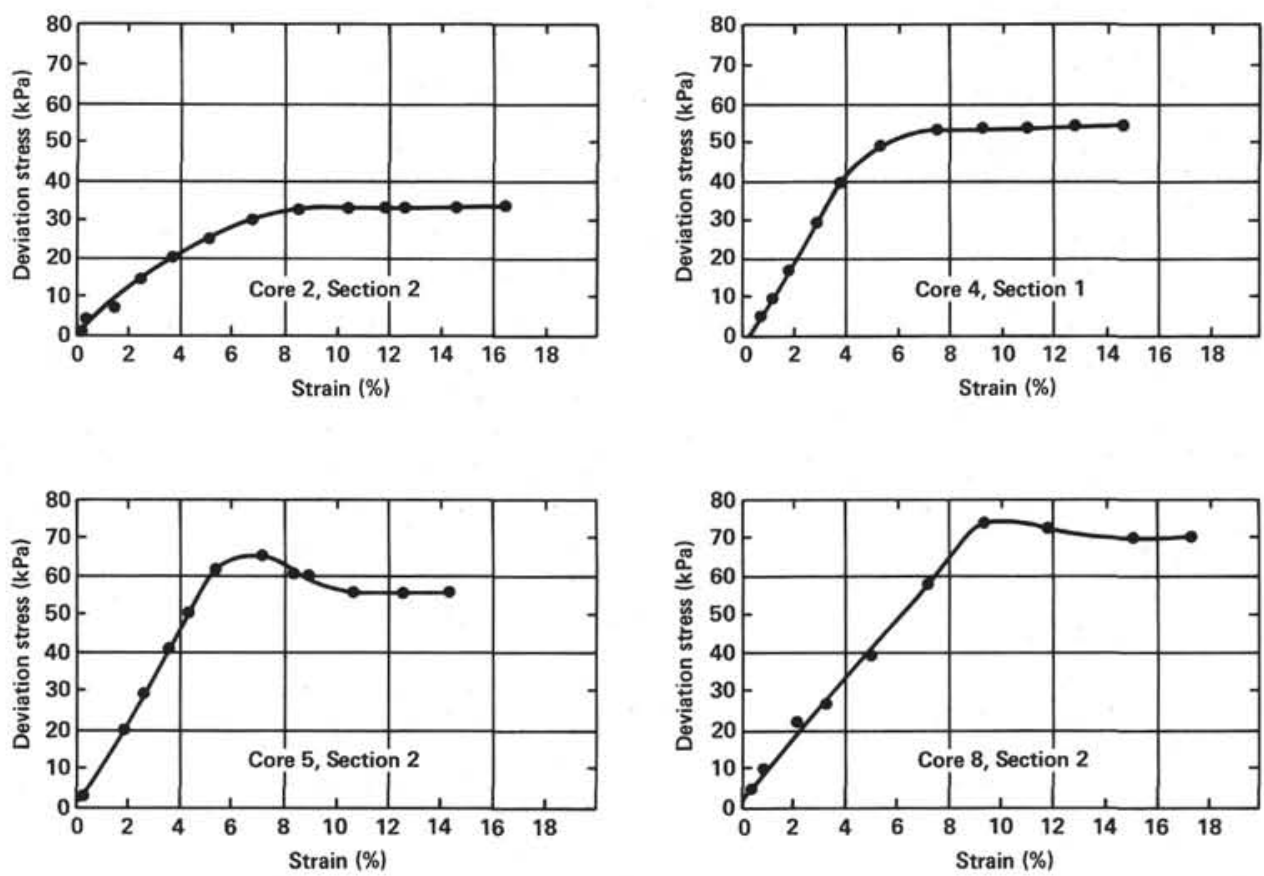

Figure 8. Typical stress-strain data for UU triaxial compression tests.
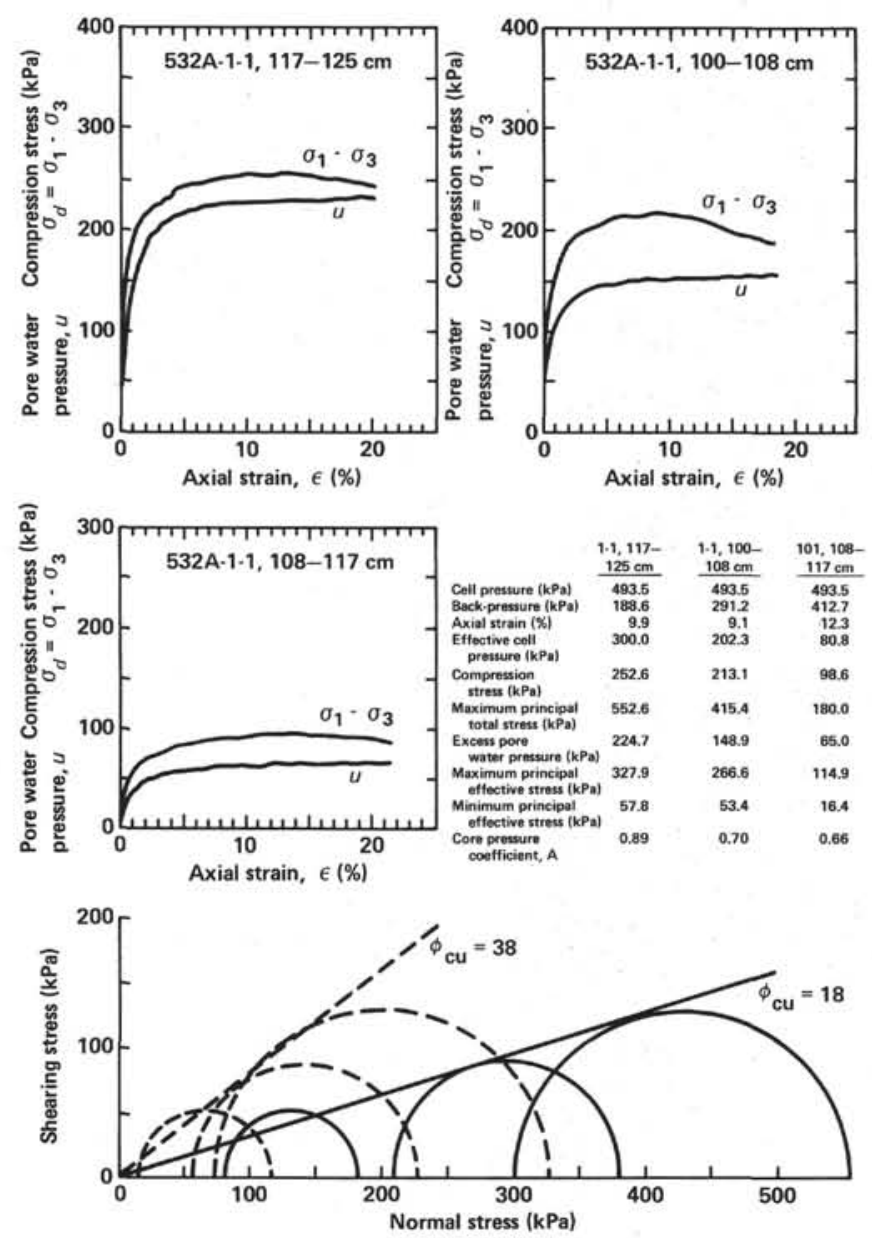

Figure 9. Summary of CIU triaxials compression test data.

\section{Theory of Consolidation}

The theory of consolidation was originally developed by Terzaghi (1925) as a linear, finite strain theory (Znidarcic and Schiffman, 1982) and was subsequently simplified to consider infinitesimal strains (Terzaghi and Frohlich, 1936). The theory concerns the change in volume of a saturated soil which results from the application of a load (self-weight or applied) and is governed by four balance relations, the flow relationship, and the material functions. The balance relationships are:

1) The equilibrium of the bulk soil mass;

2) The equilibrium of the pore water;

3) The continuity of the weight of solids;

4) The continuity of the pore water.

The flow relationship is Darcy's law. The material functions specify the relationship between the void ratio and the effective stress, and the void ratio and the coefficient of permeability. When it is assumed that the compressibility (ratio of change of void ratio to change of vertical effective stress) is constant, the coefficient of permeability is constant, and the strains are infinitesimal, the governing equation becomes,

$$
c_{v} \frac{\partial^{2} u_{e}}{\partial z^{2}}=\frac{\partial u_{e}}{\partial t}+\frac{\partial \sigma_{v}}{\partial t}
$$

where $c_{v}=$ coefficient of consolidation, $u_{e}=$ excess pore water pressure (above hydrostatic), and $\sigma_{v}=$ vertical total stress. Solutions to this equation are wellknown in the geotechnical engineering literature (Lambe and Whitman, 1969). The coefficient of consolidation $\left(c_{v}\right)$ of the sediment is determined by means of consolidation tests in the laboratory. 


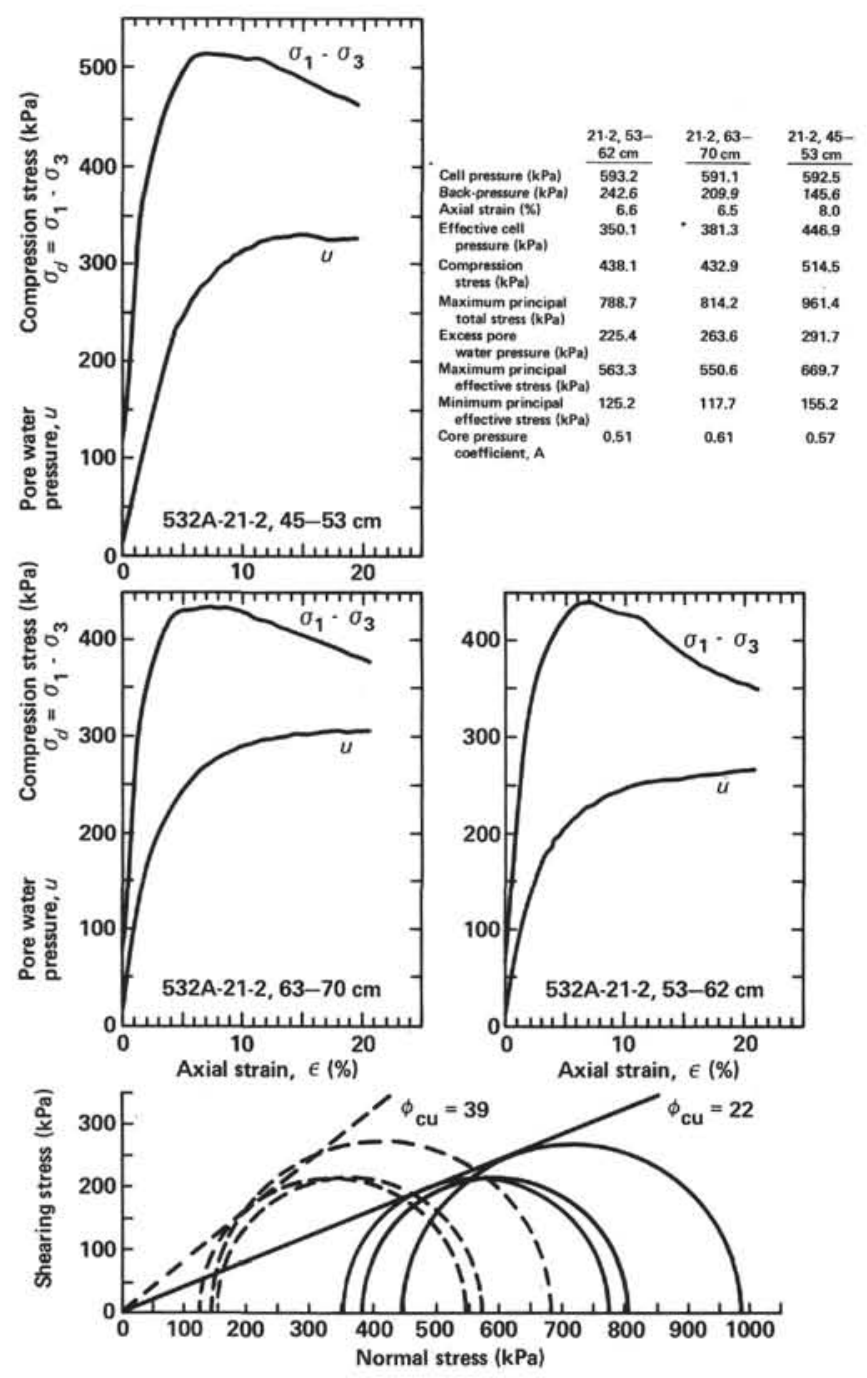

Figure 10. Summary of CIU triaxial compression test data.

Previous investigations of marine sediments, as referenced above, have clearly shown that the compressibility and the permeability of the sediments are not constant. Furthermore, the strains are finite (large). To accommodate these deviations from ideal conditions, one must use finite strain consolidation theory (Gibson et al., 1967, Gibson et al., 1981; Pane, 1981; Croce, 1981; Znidarcic, 1982).

\section{Test Procedures}

Several approaches to one-dimensional consolidation testing have been developed along different lines of reasoning, each having advantages and disadvantages. The standard test involves an incremental loading of a laterally confined and relatively thin sediment sample. The change in height of the sample is measured during the test, providing axial strain-time relationships. A complete description of the technique can be found in Lambe (1951). This method was used for samples tested at SDSU's Geonor consolidometer and for one sample at URI. A variation of this method involves the applica-
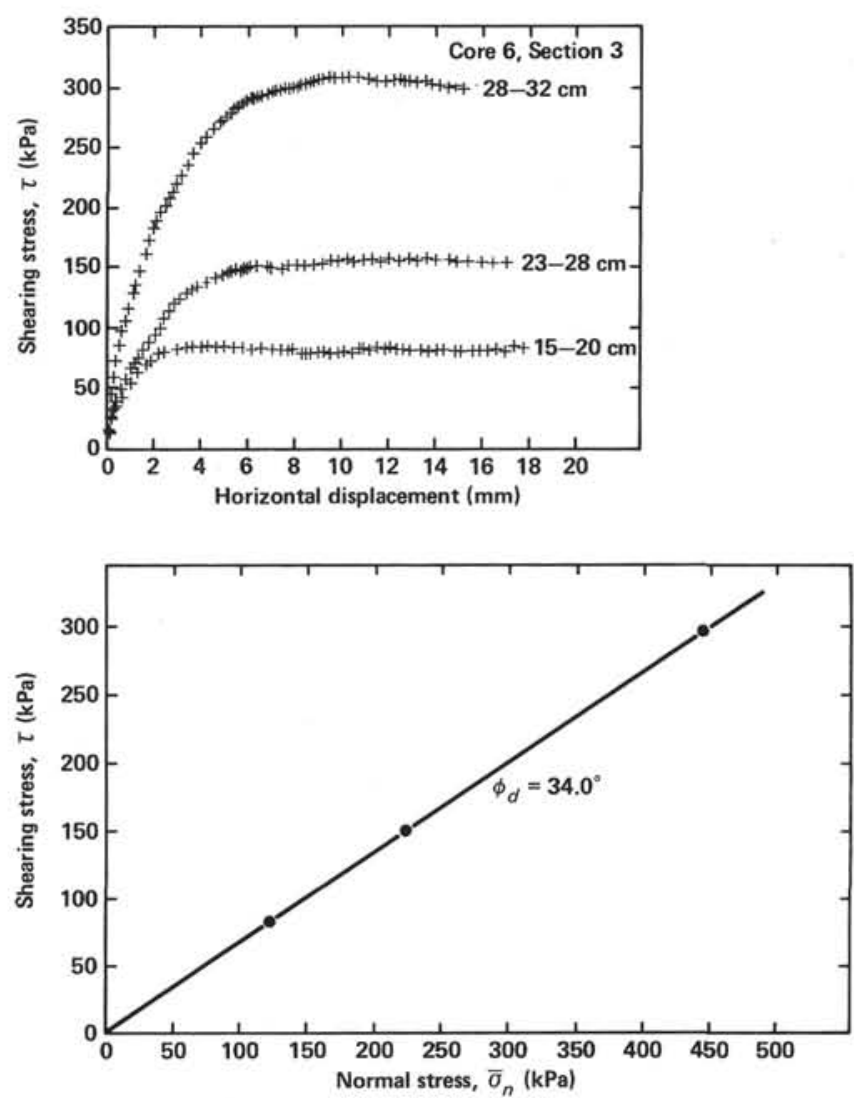

Figure 11. Summary of direct shear test.
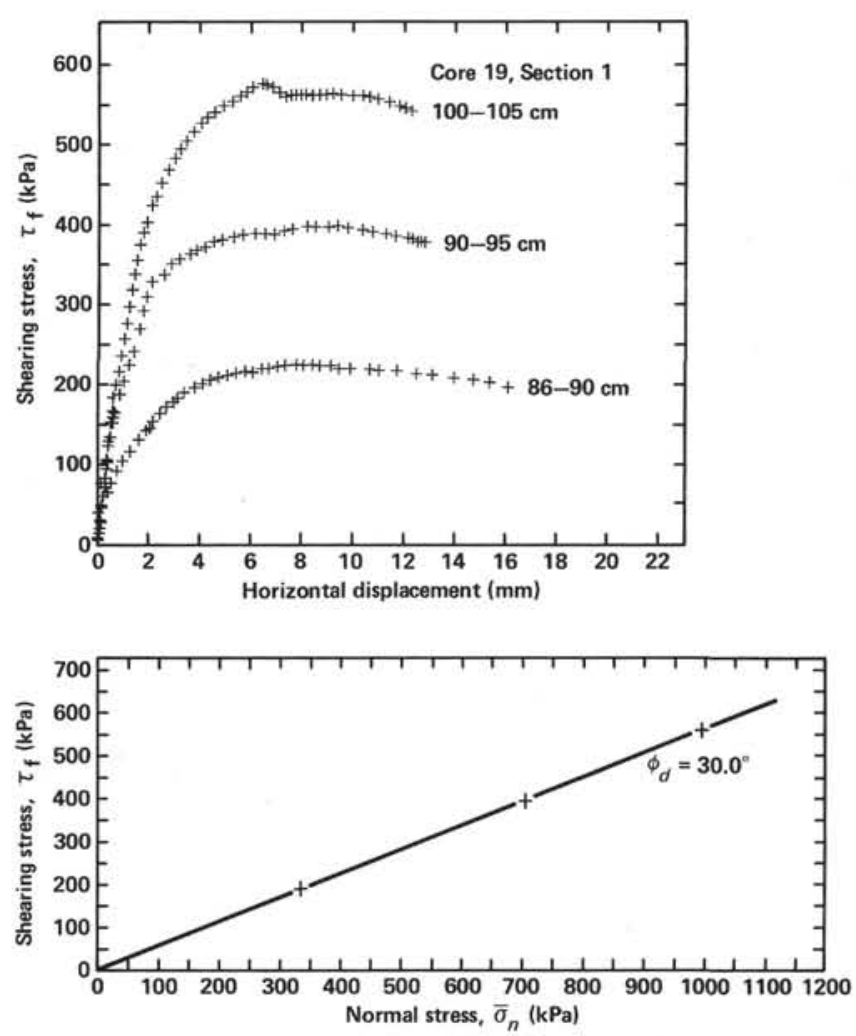

Figure 12. Summary of direct shear test. 
tion of an all-around confining pressure, or backpressure, to the sediment to redissolve gas bubbles, insuring complete saturation. The benefits of this method are presented by Lowe et al. (1964). Anteus back-pressured consolidometers modified for permeability testing were utilized both at TAMU and URI. The aforementioned samples utilized load increment ratios of $1-$ i.e., each increment is equal to the previous applied load, except for one test at URI where this ratio was 0.5 . The load decrement ratio was twice the increment ratio for the rebound phase.

A serious drawback to these methods is the time involved for completing a test, usually more than 15 days. Another testing method is the constant rate of deformation (CRD) test, which only requires a few hours per test. The CRD test imposes a deformation at a prescribed, constant rate. This procedure provides a continuous record of the changes of consolidation parameters with respect to the effective stress. The method is described in detail by Gorman et al. (1978) and Znidarcic, (1982) and the governing equations are discussed by Znidarcic (1982). The CRD tests were performed at the University of Colorado on a backpressured Geotechnique International CRD device.

\section{Data Analysis}

The oedometer test results allow determination of the properties characterizing the consolidation behavior of particular sediments; namely, permeability and compressibility. The material characterizations are presented in terms of void ratio-log effective stress, and void ratio-log permeability curves. These curves reflect the nature of the sediment's response to applied or overburden load.

During each loading increment in the standard test, the coefficient of consolidation $\left(c_{v}\right)$ is assumed to be constant by conventional Terzaghi-Frölich theory. This parameter is defined as:

$$
c_{v}=\frac{k(1+e)}{a_{v} \gamma_{w}},
$$

where $k$ is the coefficient of permeability, $\gamma_{w}$ is the unit weight of water, and $a_{v}$ is the coefficient of compressibility defined as:

$$
a_{v}=-\frac{d e}{d \sigma^{\prime}}
$$

The coefficient of consolidation can be calculated by two methods: the logarithm of time method, which fits a laboratory developed compression-time curve to a theoretical curve at $50 \%$ consolidation, and the square root of time method, which fits the theory and data at $90 \%$ consolidation (Lambe and Whitman, 1969). The coefficient of volume change $\left(m_{v}\right)$ is the slope of the normally consolidated portion of the void ratio-effective stress plot:

$$
m_{v}=\frac{a_{v}}{1+e_{o}}
$$

where $e_{o}$ is the initial void ratio. The compression index $\left(C_{c}\right)$ is the slope of the normally consolidated portion of the void ratio-log effective stress plot.

$$
C_{c}=-\frac{\Delta e}{\Delta\left(\log \sigma_{v}^{\prime}\right)}
$$

The coefficient of permeability $(k)$ is calculated in two ways. If conventional, Terzaghi-Frohlich theory is applied, then

$$
k=c_{v} \gamma_{w} m_{v}
$$

The computation of sediment consolidation parameters from CRD test results varies slightly from the above, since it entails a continuous rate of deformation along with constant monitoring of excess pore pressures. Permeability coefficients are computed by the following equation:

$$
k=\frac{v \gamma_{w} H}{2 u_{u}},
$$

where $v$ is the deformation velocity, $H$ is the sample height, and $u_{u}$ is the excess pore water pressure at the undrained boundary (Znidarcic, 1982).

Two methods of direct measurement of permeability were utilized after each load was completed on the standard, back-pressured consolidation tests. All samples processed at TAMU were tested using the falling-head technique and one sample tested at URI using the constant head method. These methods are discussed in detail by Lambe (1951) and are simple measurements of the flow rate of seawater through the consolidation sample. In addition, permeabilities were calculated from CRD test results performed at CU.

The state of consolidation of a sediment sample is known by comparing the computed in situ effective overburden stress $\left(\sigma_{o}^{\prime}\right)$ to the maximum past effective pressure with which the sample is in equilibrium (Taylor, 1948). This pressure-denoted preconsolidation pressure, or $\sigma_{c}^{\prime}$-is obtained from the $e$ - $\log \sigma_{v}^{\prime}$ curve through a graphical procedure (Casagrande, 1936). The overconsolidation ratio, OCR, is defined as:

$$
\mathrm{OCR}=\frac{\sigma_{c}^{\prime}}{\sigma_{o}^{\prime}}
$$

A value of unity represents a state of normal consolidation. If the OCR is less than one, the sample is underconsolidated. If the OCR is greater than one, the sample is overconsolidated.

\section{Consolidation Results}

The results of 51 consolidation tests are presented in Table 4 . The symbols used are those explained in the previous section, where a subscript " $o$ " identifies the condition pertaining to the sample at the computed in situ effective overburden vertical stress and the subscript " $c$ " denotes the condition prevailing at the pre- 
Table 4. Summary of consolidation and permeability results, Hole 532A.

\begin{tabular}{|c|c|c|c|c|c|c|c|c|c|c|c|}
\hline $\begin{array}{l}\text { Core- } \\
\text { Section }\end{array}$ & $\begin{array}{l}\text { Depth } \\
\text { (m) }\end{array}$ & $\begin{array}{l}\text { Test } \\
\text { group }\end{array}$ & $e_{0}$ & $\begin{array}{c}\sigma_{O}^{\prime} \\
(\mathrm{kPa})\end{array}$ & $\begin{array}{c}k_{o f} \\
(\mathrm{~cm} / \mathrm{s})\end{array}$ & $e_{c}$ & $\begin{array}{c}\sigma_{c}^{\prime} \\
(\mathrm{kPa})\end{array}$ & $\begin{array}{c}k_{c c} \\
(\mathrm{~cm} / \mathrm{s})\end{array}$ & $\begin{array}{c}k_{c f} \\
(\mathrm{~cm} / \mathrm{s})\end{array}$ & $C_{c}$ & $O C R$ \\
\hline $1-1$ & 1.25 & 1 & 3.33 & 4.5 & $6.45 \cdot 10^{-6}$ & 3.00 & 35 & $3.41 \cdot 10^{-7}$ & $3.00 \cdot 10^{-6}$ & 0.63 & 7.36 \\
\hline $2-1$ & 3.30 & 2 & 2.51 & 11.6 & $* 5.95 \cdot 10^{-7}$ & 2.25 & 50 & $3.65 \cdot 10$ & & 0.42 & 4.30 \\
\hline $2-3$ & 6.90 & 1 & 2.57 & 26.1 & $7.75 \cdot 10^{-7}$ & 2.56 & 28 & $6.92 \cdot 10^{-7}$ & $7.60 \cdot 10^{-7}$ & 0.78 & 1.07 \\
\hline $3-1$ & 8.75 & 1 & 2.34 & 34.7 & $2.44 \cdot 10^{-7}$ & 2.73 & 10 & $3.32 \cdot 10^{-7}$ & $5.91 \cdot 10^{-}$ & 0.74 & 0.29 \\
\hline $3-3$ & 11.75 & 1 & 2.28 & 47.0 & $9.70 \cdot 10^{-7}$ & 2.25 & 84 & $3.84 \cdot 10^{-7}$ & $9.00 \cdot 10^{-7}$ & 0.66 & 1.79 \\
\hline $4-2$ & 14.45 & 1 & 2.16 & 58.0 & $2.62 \cdot 10^{-5}$ & 2.11 & 75 & $5.90 \cdot 10^{-7}$ & $2.29 \cdot 10^{-5}$ & 0.65 & 1.29 \\
\hline $4-3$ & 16.30 & 2 & 3.16 & 67.0 & $\cdot 5.10 \cdot 10^{-7}$ & 3.03 & & $3.65 \cdot 10^{-7}$ & & 0.76 & 1.86 \\
\hline $5-2$ & 19.40 & 1 & 2.42 & 80.7 & $4.65 \cdot 10^{-7}$ & 2.34 & 150 & $2.30 \cdot 10^{-7}$ & $3.65 \cdot 10^{-7}$ & 0.99 & 1.86 \\
\hline $6-2$ & 23.40 & 1 & 2.29 & 96.6 & $1.41 \cdot 10^{-6}$ & 2.23 & 160 & $5.32 \cdot 10^{-7}$ & $1.24 \cdot 10^{-}$ & 0.75 & 1.66 \\
\hline $7-1$ & 26.60 & 1 & 3.43 & 108.4 & $5.20 \cdot 10^{-6}$ & 3.37 & 125 & $4.25 \cdot 10^{-7}$ & $4.60 \cdot 10^{-6}$ & 1.55 & 1.15 \\
\hline $9-1$ & 34.45 & 1 & 2.58 & 138.9 & $2.95 \cdot 10^{-7}$ & 2.55 & 170 & $2.15 \cdot 10^{-7}$ & $2.70 \cdot 10^{-7}$ & 1.04 & 1.22 \\
\hline $9-1$ & 34.56 & 4 & 2.68 & 140.3 & $3.31 \cdot 10^{-7}$ & 2.28 & 190 & $2.98 \cdot 10^{-7}$ & & 1.22 & 1.35 \\
\hline $9-2$ & 36.30 & 1 & 2.18 & 147.0 & $1.96 \cdot 10^{-7}$ & 2.32 & 120 & $9.20 \cdot 10^{-8}$ & $2.74 \cdot 10^{-7}$ & 0.87 & 0.81 \\
\hline $10-3$ & 41.75 & 2 & 2.20 & 172.0 & $\cdot 1.01 \cdot 10^{-7}$ & 2.32 & 115 & $1.21 \cdot 10^{-7}$ & & 0.89 & 0.67 \\
\hline $10-3$ & 42.00 & 3 & 2.28 & 177.0 & $3.00 \cdot 10^{-7}$ & 2.35 & 185 & & & 1.10 & 1.04 \\
\hline $11-2$ & 44.75 & 1 & 2.25 & 185.0 & $4.78 \cdot 10^{-7}$ & 2.20 & 255 & $2.64 \cdot 10^{-7}$ & $4.22 \cdot 10^{-7}$ & 0.93 & 1.38 \\
\hline $12-1$ & 48.20 & 1 & 2.08 & 200.1 & $2.23 \cdot 10^{-7}$ & 2.42 & 87 & 1.3 & 3.9 & 0.81 & 0.43 \\
\hline $12-2$ & 50.10 & 1 & 2.45 & 207.3 & $8.01 \cdot 10^{-7}$ & 2.56 & 180 & $4.57 \cdot 10^{-7}$ & $1.04 \cdot 10^{-6}$ & 1.00 & 0.87 \\
\hline $14-1$ & 57.10 & 2 & 2.44 & 233.0 & $\cdot 4.23 \cdot 10^{-7}$ & 2.57 & 160 & $6.10 \cdot 10^{-7}$ & & 1.24 & 0.69 \\
\hline $15-2$ & 62.30 & 2 & 2.19 & 253.0 & $\cdot 1.50 \cdot 10^{-7}$ & 2.10 & 345 & $1.25 \cdot 10^{-7}$ & & 1.20 & 1.36 \\
\hline $16-2$ & 66.70 & 1 & 2.26 & 270.6 & $3.66 \cdot 10^{-7}$ & 2.25 & 290 & $3.82 \cdot 10^{-7}$ & $3.65 \cdot 10^{-7}$ & 1.12 & 1.07 \\
\hline $17-2$ & 71.00 & 3 & 2.79 & 268.0 & $1.50 \cdot 10^{-8}$ & 2.27 & 291 & & & 1.40 & 1.08 \\
\hline $17-2$ & 71.30 & 1 & 2.35 & 288.1 & $1.88 \cdot 10^{-7}$ & 2.32 & 330 & $1.02 \cdot 10^{-7}$ & $1.84 \cdot 10^{-7}$ & 1.17 & 1.15 \\
\hline $18-2$ & 75.55 & 2 & 1.90 & 303.0 & $* 1.35 \cdot 10^{-7}$ & 1.80 & 405 & $1.15 \cdot 10^{-7}$ & & 1.15 & 1.34 \\
\hline $19-1$ & 79.41 & 4 & 2.70 & 317.0 & $4.83 \cdot 10^{-6}$ & 2.20 & 320 & $1.76 \cdot 10^{-7}$ & $1.25 \cdot 10^{-7}$ & 0.95 & 1.01 \\
\hline $19-2$ & 80.55 & 1 & 2.68 & 320.9 & $1.72 \cdot 10^{-7}$ & 2.88 & 250 & $3.92 \cdot 10^{-8}$ & $2.70 \cdot 10^{-7}$ & 1.46 & 0.78 \\
\hline $19-2$ & 81. & 3 & 2.71 & 323.0 & $7.00 \cdot 10^{-8}$ & 1.99 & 337 & & & 1.00 & 1.04 \\
\hline $20-2$ & 85.20 & 2 & 2.96 & 336.0 & $\cdot 5.97 \cdot 10^{-7}$ & 3.00 & 290 & $6.35 \cdot 10^{-7}$ & & 1.28 & 0.86 \\
\hline $21-2$ & 89.85 & 1 & 2.08 & 354.7 & $9.80 \cdot 10^{-8}$ & 2.18 & 370 & $9.83 \cdot 10^{-8}$ & $1.26 \cdot 10^{-7}$ & 1.13 & 1.04 \\
\hline $22-2$ & 93.80 & 2 & 2.35 & 371.0 & $\cdot 3.00 \cdot 10^{-7}$ & 2.33 & 390 & $2.95 \cdot 10^{-7}$ & & 1.24 & 1.05 \\
\hline $23-1$ & 96.90 & 1 & 2.18 & 382.1 & $9.40 \cdot 10^{-7}$ & 2.05 & 495 & $2.70 \cdot 10^{-7}$ & $7.38 \cdot 10^{-7}$ & 0.87 & 1.30 \\
\hline $24-2$ & 102.95 & 1 & 2.28 & 411.9 & $4.11 \cdot 10^{-7}$ & 2.46 & 320 & $1.57 \cdot 10^{-7}$ & $5.98 \cdot 10^{-7}$ & 1.07 & 0.78 \\
\hline $25-2$ & 107.10 & 2 & 1.76 & 430.0 & $\cdot 1.35 \cdot 10^{-7}$ & 1.73 & 470 & $1.90 \cdot 10^{-7}$ & & 0.91 & 1.09 \\
\hline $26-2$ & 111.30 & 1 & 2.26 & 448.2 & $5.80 \cdot 10^{-7}$ & 2.38 & 390 & $2.34 \cdot 10^{-7}$ & $7.55 \cdot 10^{-7}$ & 0.63 & 0.87 \\
\hline $28-2$ & 119.60 & 2 & 1.54 & 486.0 & $\cdot 7.70 \cdot 10^{-8}$ & 1.52 & 530 & $7.30 \cdot 10^{-8}$ & & 1.03 & 1.09 \\
\hline $29-2$ & 124.75 & 2 & 2.08 & 508.0 & $\cdot 2.30 \cdot 10^{-7}$ & 2.11 & 469 & $2.45 \cdot 10^{-7}$ & & 1.08 & 0.91 \\
\hline $30-1$ & 128.00 & 1 & 1.87 & 523.5 & $2.39 \cdot 10^{-8}$ & 1.84 & 690 & $2.88 \cdot 10^{-8}$ & $2.19 \cdot 10^{-8}$ & 1.14 & 1.32 \\
\hline $31-1$ & 132.10 & 2 & 1.41 & 544.0 & $\bullet 6.10 \cdot 10^{-8}$ & 1.38 & 640 & $5.60 \cdot 10^{-8}$ & & 0.72 & 1.18 \\
\hline $32-2$ & 139.50 & 2 & 1.23 & 566.0 & $-5.50 \cdot 10^{-8}$ & 1.18 & 720 & $4.70 \cdot 10^{-8}$ & & 0.65 & 1.27 \\
\hline $33-2$ & 142.10 & 2 & 1.37 & 609.0 & $\cdot 4.15 \cdot 10^{-8}$ & 1.38 & 590 & $4.30 \cdot 10^{-8}$ & & 0.71 & 0.97 \\
\hline $34-1$ & 145.20 & 1 & 1.46 & 618.9 & $5.55 \cdot 10^{-8}$ & 1.45 & 650 & $4.29 \cdot 10^{-8}$ & $5.41 \cdot 10^{-8}$ & 0.57 & 1.05 \\
\hline $34-3$ & 147.50 & 2 & 1.26 & 636.0 & $\cdot 5.00 \cdot 10^{-8}$ & 1.23 & 760 & $4.60 \cdot 10^{-8}$ & & 0.76 & 1.19 \\
\hline $35-3$ & 151.80 & 2 & 1.21 & 663.0 & $\bullet 5.30 \cdot 10^{-8}$ & 1.23 & 510 & $5.70 \cdot 10^{-8}$ & & 0.56 & 0.77 \\
\hline $36-2$ & 155.10 & 1 & 1.31 & 677.1 & $4.12 \cdot 10^{-8}$ & 1.31 & 680 & $1.49 \cdot 10^{-8}$ & $4.12 \cdot 10^{-8}$ & 0.67 & 1.01 \\
\hline $38-1$ & 162.00 & 1 & 1.26 & 721.6 & $2.00 \cdot 10^{-6}$ & 1.56 & 200 & $2.10 \cdot 10^{-8}$ & $4.45 \cdot 10^{-6}$ & 0.59 & 0.28 \\
\hline $40-2$ & 170.05 & 1 & 1.24 & 771.8 & $1.73 \cdot 10^{-8}$ & 1.50 & 310 & $1.23 \cdot 10^{-8}$ & $5.10 \cdot 10^{-8}$ & 0.58 & 0.40 \\
\hline $41-1$ & 173.60 & 2 & 1.35 & 791.0 & $\cdot 4.50 \cdot 10^{-8}$ & 1.32 & 890 & $4.20 \cdot 10^{-8}$ & & 0.92 & 1.13 \\
\hline $42-3$ & & 2 & 1.17 & & $\cdot 3.40 \cdot 10^{-8}$ & 1.20 & 710 & $3.80 \cdot 10^{-8}$ & & 0.55 & 0.86 \\
\hline 44-1 & 186.45 & 1 & 1.24 & 859.7 & $7.79 \cdot 10^{-8}$ & 1.36 & 460 & $6.07 \cdot 10^{-8}$ & $1.91 \cdot 10^{-7}$ & 0.46 & 0.54 \\
\hline $47-2$ & 197.40 & 1 & 0.99 & 944.2 & $4.45 \cdot 10^{-8}$ & 0.97 & 1100 & $2.55 \cdot 10^{-8}$ & $3.95 \cdot 10^{-8}$ & 0.65 & 1.17 \\
\hline $47-3$ & 198.35 & 2 & 1.10 & 949.0 & $2.95 \cdot 10^{-8}$ & 1.12 & 860 & $3.04 \cdot 10^{-8}$ & & 0.52 & 0.91 \\
\hline
\end{tabular}

Note: Test group: 1 = TAMU, $2=\mathrm{CU}, 3=\mathrm{SDSU}, 4=\mathrm{URI} ; k_{\text {of }}=$ coefficient of permeability at effective overburden pressures measured by falling head test; $k_{c c}=$ coefficient of permeability at preconsolidation pressure, computed from the results of consolidation test; $k_{c f}=$ coefficient of permeability at preconsolidation pressure, measured by falling head test; ${ }^{*}=$ constant rate of deformation (CRD) test.

consolidated effective stress. The latter data most likely approach the in situ conditions of the sediment. Typical $e$ - $\log \sigma_{v}^{\prime}$ curves, from which much of these data were obtained, are presented in Figure 13, where results obtained from three different consolidation testing methods are also presented. The distinct break in these curves, from the reload to virgin portions of the graphs, is characteristic of sediments with little or no remolding. This, therefore, suggests that the majority of the samples tested were relatively undisturbed. Overconsolidation ratios vary from a surface high of 7.4 in Core 1 , Section 1 to a low of 0.28 in Core 38, Section 1. Overall, the OCR for this section decreases downhole, with some variation around a normally consolidated state $(\mathrm{OCR}=1)$.

The maximum, minimum, and average values of the consolidation coefficient, $c_{v}$, and for the compression index, $C_{c}$, for Hole 532A are presented in Table 5. These values are obtained from the portion of the $e-\log \sigma_{v}^{\prime}$ curve beyond the preconsolidation or calculated in situ overburden. Also shown in the table is the range of values for the permeability coefficient from consolidation

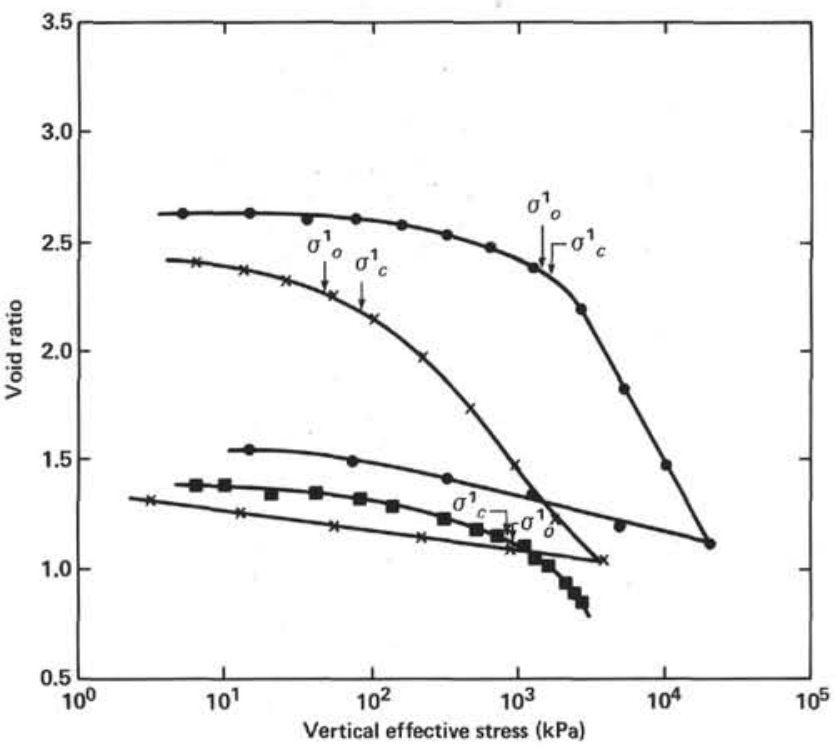

Figure 13. Typical void ratio effective stress curves. 
Table 5. Range and average values of consolidation properties for sediments from DSDP Hole 532A computed from consolidation tests.

\begin{tabular}{|c|c|c|c|}
\hline Properties & Minimum & Maximum & Average \\
\hline $\begin{array}{l}\text { Coefficient of consolidation, } \\
c_{y}\left(\mathrm{~cm}^{2} / \mathrm{s}\right)\end{array}$ & $4.86 \times 10^{-4}$ & $5.0 \times 10^{-2}$ & $3.9 \times 10^{-3}$ \\
\hline $\begin{array}{l}\text { Compression index, } C_{C} \\
\text { Coefficient of permeability, } \\
k_{C}(\mathrm{~cm} / \mathrm{s})\end{array}$ & $\begin{array}{l}0.42 \\
1.23 \times 10^{-8}\end{array}$ & $\begin{array}{l}1.55 \\
6.92 \times 10^{-7}\end{array}$ & $\begin{array}{l}0.9 \\
2.11 \times 10^{-7}\end{array}$ \\
\hline
\end{tabular}

testing, obtained through interpolation of the coefficient at the preconsolidated effective stress.

\section{Permeability Results}

Direct measurements of permeability for sediments from this site are presented in Table 5 at $\sigma_{o}^{\prime}$ and $\sigma_{c}^{\prime}$ conditions. The range of falling head permeability measurements at the preconsolidated state varies from $2.29 \times$ $10^{-5} \mathrm{~cm} / \mathrm{s}$ to $2.19 \times 10^{-8} \mathrm{~cm} / \mathrm{s}$, representing fairly high permeability coefficients for the corresponding void ratios. The linear relationship of void ratio and log of permeability is apparent in Figure 14, where both direct and indirect measurements of this parameter are shown. Deviation from this linearity is noticeable during the initial loading phase of consolidation, in which slow and small decreases in void ratio are accompanied by much larger decreases in permeability. This is most likely a result of the sample closing small cracks and ensuring good sidewall contact with the confining ring, both of which offer fast flow paths.

\section{DISCUSSION AND CONCLUSIONS}

This section presents the discussion and conclusions derived from the analysis of index, strength, and consolidation/permeability properties.

\section{Index Properties}

Three lithologic subunits (1a, 1b, and 1c) were identified for Hole 532A based on previous work on Hole 532. The three subunits consisted of the following: (1) Subunit 1a-foram-nannofossil marl and ooze (0-49.5

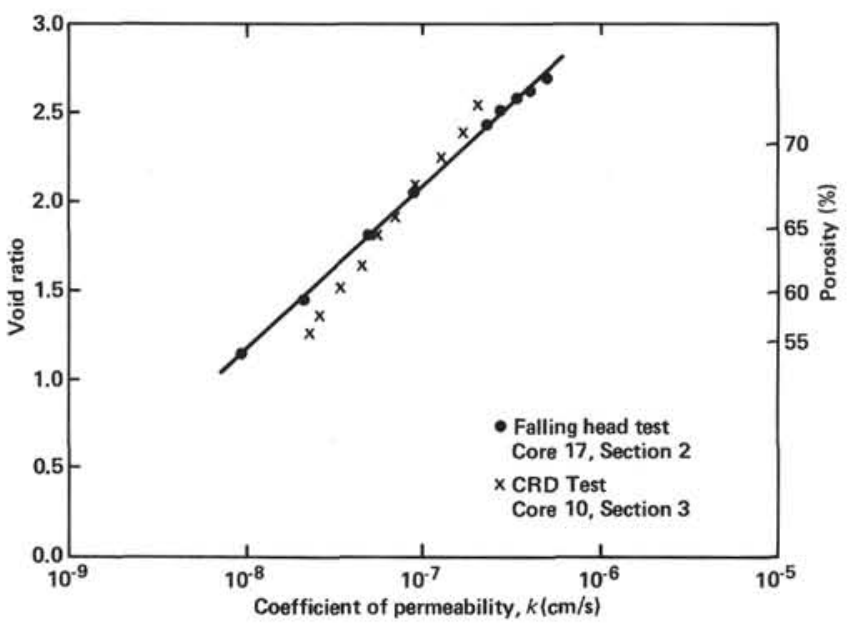

Figure 14. Relationship of permeability to void ratio and porosity. m), (2) Subunit 1b-diatom-nannofossil marl (49.5$114.0 \mathrm{~m}$ ), and (3) Subunit 1c-nannofossil marl (114.0$200.0 \mathrm{~m})$. The calcium carbonate $\left(\mathrm{CaCO}_{3}\right)$ content of the sediment ranged from 11 to $76 \%$. The average amount of $\mathrm{CaCO}_{3}$ decreased from a maximum $(60 \%)$ at the mudline (Pleistocene) to a minimum $(25 \%)$ at approximately $80 \mathrm{~m}$ depth (late Pliocene) after which it increased again to a value of $57 \%$ at $200 \mathrm{~m}$ (late Miocene). The specific gravity of the sediment is uniform with depth, with an average value of 2.64 and a range of 2.49-2.73.

Clay and silt size material constitute the major portion of sediment present in the core. The amount of clay size material (smaller than $0.002 \mathrm{~mm}$ ) ranges from $25 \%$ at the mudline to $70 \%$ at a depth of $200 \mathrm{~m}$. The corresponding sand sized material (larger than $0.074 \mathrm{~mm}$ or sieve No. 200) ranged from $35 \%$ at the mudline to a relatively constant $1-2 \%$ below a depth of $36 \mathrm{~m}$. The sand sized materials in the upper layers are probably the remains of relatively intact foraminifer tests (average size $=1 \mathrm{~mm}$ ). Below a certain depth of burial, the resulting effective stress would tend to break these tests into smaller particles, therefore causing the sand fraction to essentially disappear.

The average water content varies from a high of $155 \%$ at the mudline to a value of $90 \%$ at a depth of $15 \mathrm{~m}$. From 15 to $120 \mathrm{~m}$ depth the water content is relatively constant. After $120 \mathrm{~m}$ it decreases almost linearly with depth to a value of $50 \%$ at $200 \mathrm{~m}$. The large decrease in water content in the first $15 \mathrm{~m}$ of depth below the mudline results in large part from the depth of burial, but it also probably resulted in part from the breakdown in foraminifer tests and the release of the contained water.

The liquid $(L L)$ and plastic $(P L)$ limits are rather variable $(L L=66-152 \%, P L=40-100 \%)$ and show no consistent observable relationship to sediment type (subunit type). Based on these data, the sediment classification in accordance with the Unified Classification System is MH or silt of high plasticity. A review of the natural water content indicates that it is higher than the $L L$ in Subunits 1 a and 1 b but lower than $L L$ in Subunit 1c. These results correspond to the presence of foramnannofossil marl and diatom-nannofossil material. Both of these particles are relatively porous and can contain a large amount of water. The presence of this water in the skeletal remains tends to indicate a water content higher than would be present in the soil matrix itself.

The wet-bulk density was found to be relatively uniform from $0-120 \mathrm{~m}$ below the mudline, ranging from 1.38 to $1.50 \mathrm{Mg} / \mathrm{m}^{3}$. From 120 to $200 \mathrm{~m}$ the wet-bulk density increased linearly with depth from $1.47-1.75$ $\mathrm{Mg} / \mathrm{m}^{3}$. The density gradient decreased from 0 to $50 \mathrm{~m}$ depth as would be predicted for a porous calcareous material as present in Subunit 1a (foram-nannofossil marl). From 50 to $80 \mathrm{~m}$, corresponding to the upper half of Subunit $1 \mathrm{~b}$ (diatom-nannofossil), the density gradient remained relatively constant. Below $80 \mathrm{~m}$ the density gradient increased linearly. This corresponds to the bottom half of Subunit 1b and Subunit 1c (nannofossil). These results are contrary to previously published data 
showing that the density gradients for calcareous and diatomaceous materials decrease with depth.

\section{Strength Properties}

Analysis of the index properties indicated that there were no major lithologic differences throughout the sediment core from Hole 532A. The consolidation data indicated a normally consolidated deposit. It is therefore expected that the undrained shear strength $\left(s_{u}\right)$ will increase with depth, and the ratio of undrained shearing resistance to effective normal stress $s_{u} / \sigma_{v}^{\prime}$ will be approximately a constant.

Figure 15 is a comparison of linear least-square fits to the eight sets of UU strength data presented in Table 3. Instead of plotting shear strength against depth, shear strength is plotted against the in situ effective vertical stress, $\sigma_{v}^{\prime}$, for vane and UU, tests. This figure permits a direct comparison between the results of vane shear and UU triaxial tests and allows the $s_{u} / \sigma_{v}^{\prime}$ normalized strength parameter to be determined from the slope of each line.

The UU test data with an $s_{u} / \sigma_{\nu}^{\prime}$ of 0.18 compares relatively well with the vane results $\left(s_{u} / \sigma_{y}^{\prime}=0.19\right)$. This is to be expected since both measure undrained shearing resistance at the initial water content. However, these values are both low compared with the range of 0.25 to 0.35 for marine clays (Lambe and Whitman, 1969), and are very low when compared with typical values for sediments with high carbonate content reported in the literature (Nacci et al, 1974). This possibly results from disturbance and stress change upon sampling.

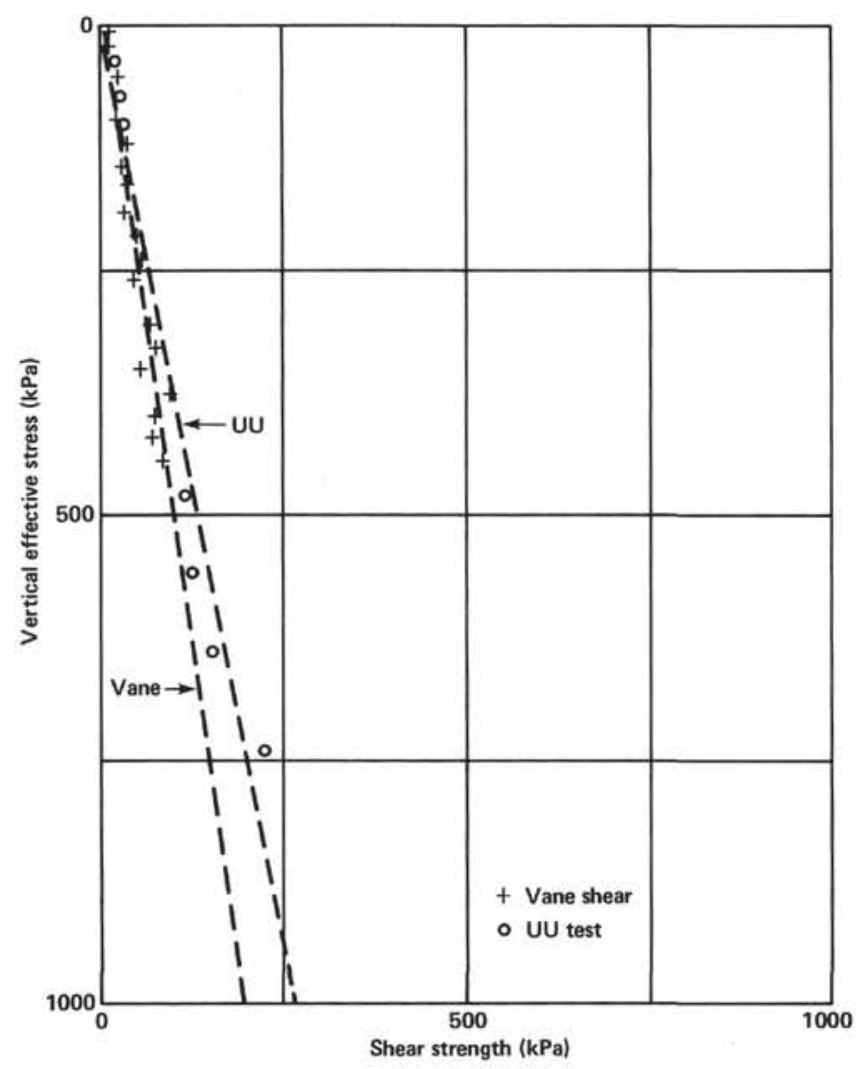

Figure 15. Effective overburden stress versus shear strength.
The following conclusions can be drawn from the results of the strength tests:

1) Vane shear and unconsolidated undrained triaxial compression test data are in reasonable agreement. However, both test results appear to underestimate the in situ undrained shear strength of the sediment.

2) The triaxial and direct shear tests indicated that $c^{\prime}=0$ and that $\phi^{\prime}$ is in the range of 30 to 39 degrees.

3) No differences in shear strength due to lithological changes were noted.

\section{Consolidation/Permeability Properties}

The measured consolidation characteristics of this site are all similar, regardless of the test method employed. The $e$-log $\sigma_{v}^{\prime}$ curves indicate fairly well-preserved and undisturbed samples, with the overall form of these resembling the carbonate and terrigenous profiles discussed by Hamilton (1976). The variation with depth of effective overburden stress (computed from submerged unit weight) is shown in Figure 16, along with preconsolidation effective stress obtained from the tests. The ratio of these two stresses, OCR, is also plotted. The data in Figure 16 indicate apparently overconsolidated sediments at surface and a fluctuating state around normal consolidation below this. An exception to this normal state is noticeable between 160 and $185 \mathrm{~m}$ sub-bottom, where the sediment might be underconsolidated.

Numerous factors affect the state of consolidation, modifying the simple mechanical loading process and producing large deviations from the expected. The mechanical aspect of consolidation involves reduction of void space and is dependent on permeability among other sediment properties. The coefficient of permeability in these sediments at the preconsolidated state averages $8.91 \times 10^{-7} \mathrm{~cm} / \mathrm{s}$, indicating a fairly permeable sediment. The mechanical properties of sediment and its behavior also depend on the in situ microfabric (i.e., particle-particle relationships). Pressure solution, cementation, internal organic matrices, grain size, sedimentary history, and a number of other factors affect the consolidation state. High values of OCR near the mudline are not reflective of true overconsolidation; they result from the fact that the effective stress approaches zero, thus any internal strength of the sediment, such as cohesion, provides an apparent overconsolidation. Underconsolidation, on the other hand, may result from continuous loading of the column with insufficient accompanied drainage, though this would not appear to be the case for this site considering the high permeability. Also, production of gas may increase pore pressures, thus reducing the effective stress and preventing normal consolidation.

Permeabilities obtained for this site are graphically displayed in Figure 17. The permeability coefficients are those interpolated from the $e$-log $k$ linear relationships discussed earlier at the in situ void ratio $\left(e_{c}\right)$. As seen in Figure 17, direct and indirect measurements provide fairly similar results, although indirect results tend to yield somewhat lower permeabilities. The former may result from the effects of seepage-induced consolidation in the falling head tests (Pane et al., 1983). Overall, the 


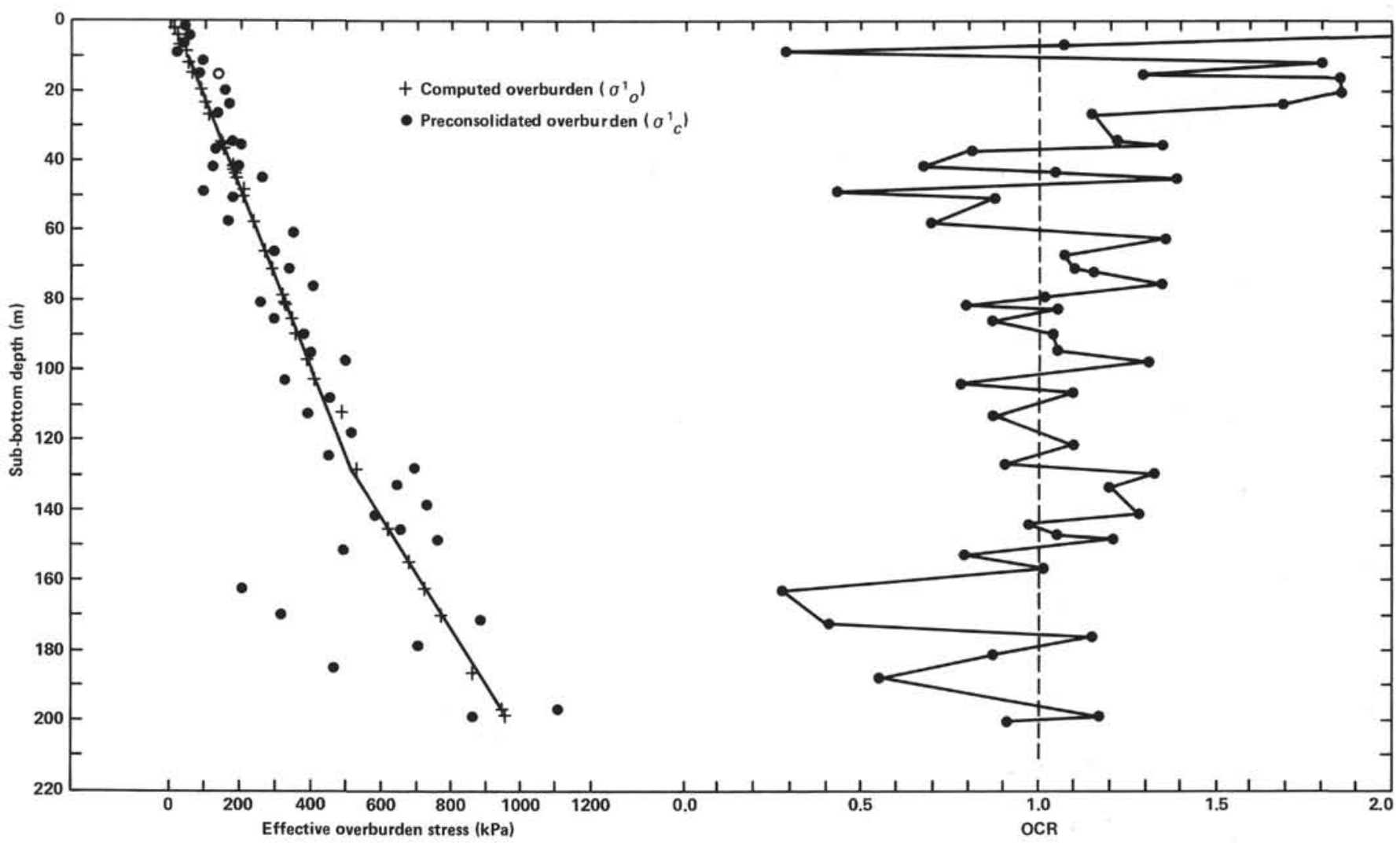

Figure 16. Variation of effective overburden stress and OCR with depth.

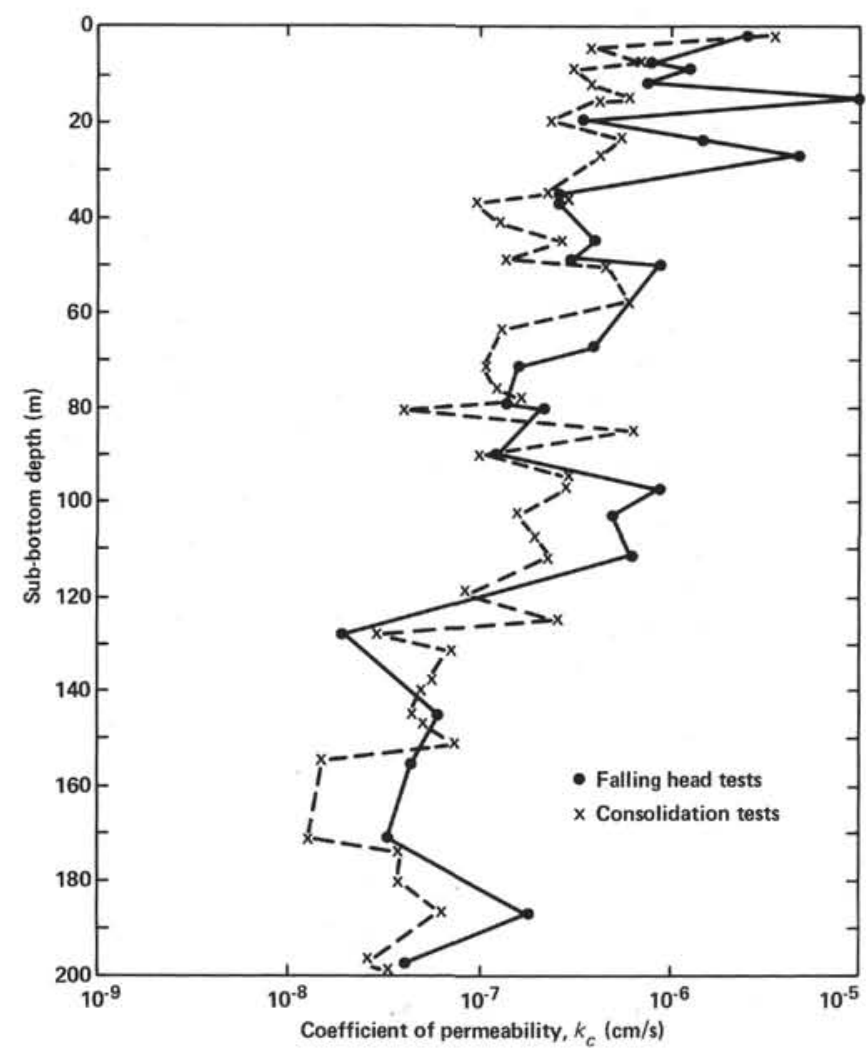

Figure 17. Variation of permeability with depth. permeability in this section decreases with depth, yet it remains somewhat high as compared to those reported by Bryant et al. (1981) for silty clays and clayey silts at similar void ratios.

Consolidation studies provide useful engineering properties, but in addition to this, they allow a better understanding of the relationship of changes in physical properties under increasing vertical stress. A comparison of the field consolidation data to laboratory results is helpful in assessing the aspects of loading in the actual sedimentary column. Figure 18 is a plot of void ratio at $\sigma_{o}^{\prime}$ and $\sigma_{c}^{\prime}$ with depth, also showing the linear regression curve for the $e_{c}$ data which represents the best approximation to a field virgin curve. The coefficient of compressibility, $a_{y}$, for this curve is $1.81 \times 10^{-3}$ and has a compression index, $C_{c}$, of 1.94 . These data are significantly different from the average data for this site as computed from consolidation testing in which $a_{v}=0.84$ $\times 10^{-3}$ and $C_{c}=0.897$.

A field curve of permeability and void ratio is shown in Figure 19. This plot again reflects the linearity of the e-log $\mathrm{k}$ data as previously shown for consolidation and falling-head laboratory measurements. A review of all laboratory permeability data shows that a decrease of one order of magnitude in the permeability coefficient corresponds to approximately a one unit decrease in void ratio, which compares closely with the field curve. The comparison of the field and laboratory results for consolidation parameters would suggest that although mechanical response to overburden is the governing as- 


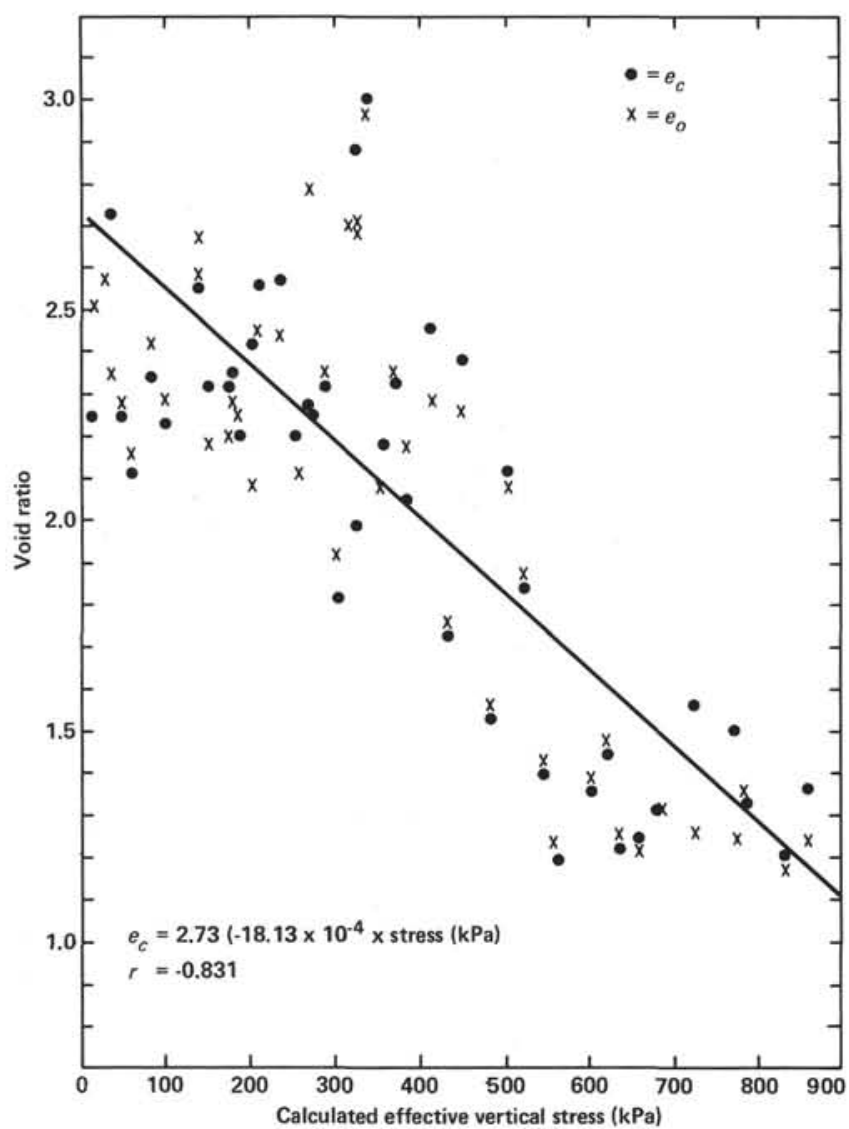

Figure 18. Field consolidation curves. pect behind alteration of physical properties for this site, factors are certainly active in constraining the mechanics of these sediments.

Changes in physical properties, consolidation parameters, and permeabilities for Hole 532A are principally functions of the mechanics of sediment response to overburden. This dependency is more pronounced below a depth of $115 \mathrm{~m}$ sub-bottom as reflected by the linearity of the decrease in void ratio with overburden and by changes in physical properties with depth. Above this depth, a higher degree of variability may be responding to fluctuations of water content, grain size and clay mineralogy, calcium carbonate content, gas, or other characteristics altering the sediment's composition and structure.

In general, the consolidation aspects of this boring are normal for calcareous-terrigenous sediments, being overconsolidated near surface with a quick transition towards a column fluctuating around a normally to slightly underconsolidated state. Noticeable excursions from this trend are found, however, at 50,100, and $160 \mathrm{~m}$ sub-bottom, where strong shifts towards underconsolidation occur. Associated with these previous zones are overlying layers of overconsolidated material. Interestingly, the underconsolidated shifts are correlated to intervals of marked decreases of calcium carbonate, water content and shear strength, and to increases of clay content. Finally, analysis of seismic reflectors from this area suggests that hiatuses exist at about 90 and $160 \mathrm{~m}$ below mudline, which may indeed correlate to the zones overlying these underconsolidated sections. These hiatuses are representative of periods of

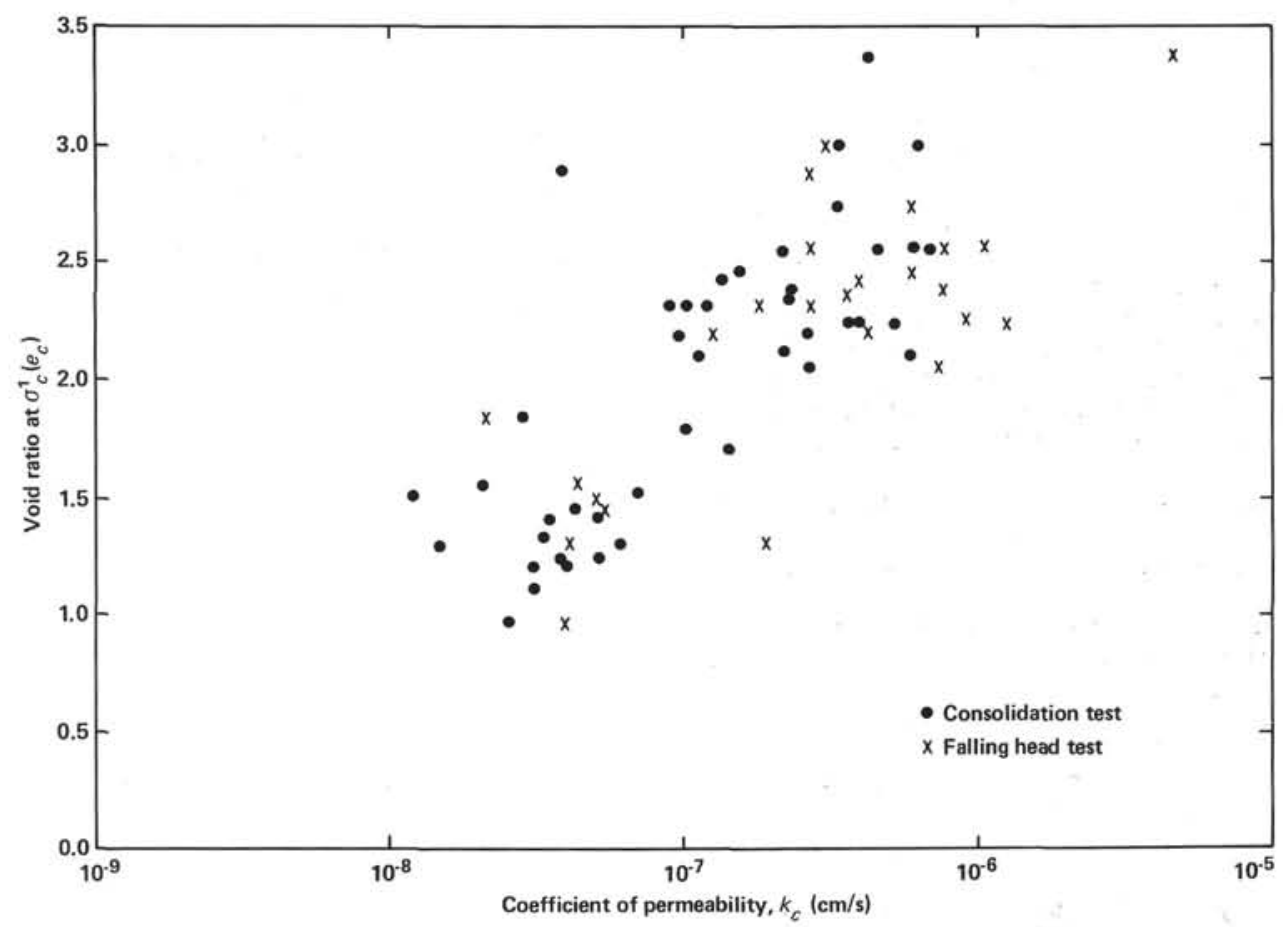

Figure 19. Relationship of permeability to void ratio for natural sediments. 
nondeposition or erosion which can easily lead to the overconsolidated state observed.

Permeability is directly dependent on void ratio as reflected in the linearity of $e-\log k$ relationships. The sediments here have higher than average permeabilities for the corresponding void ratios as compared to other marine sediments of similar composition (Bryant et al., 1981). Despite the higher permeabilities, an analogous trend of decreasing permeability with depth is observed.

Physical properties, consolidation, and permeabilities have an erratic nature in the upper section at this site. This is not representative of a normally consolidating sequence and thus reflects other variables involved in the constructed sediment fabric. The role of sedimentary consolidation processes, however, becomes increasingly defined downhole and eventually dominates the observed changes of physical properties.

\section{ACKNOWLEDGMENT}

The authors express their appreciation to the Deep Sea Drilling Program, Scripps Institution of Oceanography, for making the sediment cores available for this study, and to the Lamont Doherty Geological Observatory for providing laboratory space for the initial core processing operations. The studies reported herein were partially supported by a research grant from the Office of Naval Research (Grant No. N0014-79-C-0004 to Oregon State University), another research grant from National Science Foundation (Grant No. OCE-8118044 to San Diego State University), and a grant from Joint Oceanographic Institutions, Inc. to the consortium. These valuable contributions are gratefully acknowledged.

\section{REFERENCES}

American Society for Testing and Materials, 1981. Annual Book of ASTM Standards, Pt. 19: Philadelphia (ASTM).

Bishop, A. W., and Henkel, D. J., 1957. The Measurement of Solid Properties in the Triaxial Test: London (Edward Arnold, Ltd.).

Bouma, A. H., 1969. Methods for the Study of Sedimentary Structures: New York (Wiley Interscience).

Bryant, W. R., Bennett, R. H., and Katherman, C. F., 1981. Shear strength, consolidation porosity, and permeability of oceanic sediments. In Emiliani, C. (Ed.), The Sea (Vol. 7), The Oceanic Lithosphere: New York (Wiley), pp. 1555-1615.

Casagrande, A., 1936. The determination of the pre-consolidation load and its practical significance. Proc. First Int. Conf. Soil Mech. Found. Eng., 3:60-64.

Croce, P., 1981. Evaluation of consolidation theories by centrifugal model tests [M.S. thesis]. University of Colorado, Boulder.

Gibson, R. E., England, G. L., and Hussey, M. J. L., 1967. The theory of one-dimensional consolidation of saturated clays: I. Finite non-linear consolidation of thin homogeneous layers. Geotechnique, 17:261-273.

Gibson, R. E., Schiffman, R. L., and Cargill, K. W., 1981. The theory of one-dimensional consolidation of saturated clays: II. Finite nonlinear consolidation of thick homogeneous layers. Can. Geotech. J., 18:280-293.

Gorman, C. T., Hopkins, T. C., Deen, R. C., and Drnevich, V. P., 1978. Constant rate of strain and controlled gradient consolidation testing. Geotech. Test. J., 1:3-15.

Hamilton, E. L., 1976. Variations of density and porosity with depth in deep-sea sediments. J. Sediment. Petrol., 46:280-300.

Lambe, T. W., 1951. Soil Testing for Engineers: New York (John Wiley).

Lambe, T. W., and Whitman, R. V., 1969. Soil Mechanics: New York (John Wiley).

Lee, H. J., 1973. Measurements and estimates of engineering and other physical properties, Leg 19. In Craeger, J. S., Scholl, D. W., et al., Init. Repts. DSDP, 19: Washington (U.S. Govt. Printing Office), 701-719.

Lee, H. J., Olson, H. W., and von Huene, R., 1973. Physical properties of deformed sediments from Site 181. In Kulm, L. D., von
Huene, R. et al., Init. Repts. DSDP, 18: Washington (U.S. Govt. Printing Office), 701-719.

Lowe, J., Zaccheo, P. F., and Feldman, H. S., 1964. Consolidation testing with back pressure. J. Soil Mech. Found. Div. Am. Soc. Chem. Eng., 90:69-86.

Monney, N. T., 1974. An analysis of the vane shear test at varying rates of shear. In Inderbitzen, A. L. (Ed.), Deep-Sea Sediments: New York (Plenum).

Muller, G., and Gastner, M., 1971. The "Karbonat Bombe," A simple device for the determination of carbonate content in sediments, soils and other materials. N. Jahrb. Mineral. Mh., 10:466-469.

Nacci, V. A., Kelly, W. E., Wang, M. C., and Demars, K. R., 1974. Strength and stress-strain characteristics of cemented deep-sea sediments. In Inderbitzen, A. L. (Ed.), Deep-Sea Sediments: New York (Plenum).

Noorany, I., 1982. Phase Relations in Marine Soils: San Diego State University (Department of Civil Engineering).

Pane, V., 1981. One-dimensional finite strain consolidation [M.S. thesis]. University of Colorado, Boulder.

Pane, V., Croce, P., Znidarcic, D., Ko, H-Y., Olsen, H. W., and Schiffman, R. L., 1983. "Effects of consolidation on permeability measurements for soft clay." Geotechnique, 33:67-72.

Shephard, L. E., 1981. Geotechnical properties of select convergent margin sediments [Ph.D. dissert.]. Texas A\&M University, College Station.

Shephard, L. E., and Bryant, W. R., 1980. Consolidation characteristics of Japan Trench sediments. In Scientific Party, Init. Repts. DSDP, 56, 57, Pt. 2: Washington (U.S. Govt. Printing Office), 1201-1206.

Shephard, L. E., Bryant, W. R., and Chiou, W. A., 1982. Geotechnical properties of Middle America Trench sediments, DSDP Leg 66. In Watkins, J. S., Moore, J. C., et al., Init. Repts. DSDP, 66: Washington (U.S. Govt. Printing Office), 475-504.

Skempton, A. W., 1954. The pore-pressure coefficient A and B. Geotechnique, 4(4):143-147.

1970 . The consolidation of clays by gravitational compaction. J. Geol. Soc. London, 125:373-411.

Taylor, D. W., 1948. Fundamental of Soil Mechanics: New York (John Wiley).

Terzaghi, K., 1925. Principles of soil mechanics settlement and consolidation of clay. Eng. New Record, pp. 874-878.

Terzaghi, K., and Fröhlich, O. K., 1936. Theorie der Setzung von Tonschichten; eine Einfuhrung in die Analytische Tonmechanik: Leipzig, Germany (F. Deuticke).

Trabant, P. K., 1972. Consolidation characteristics and related geotechnical properties of sediments retrieved by the Glomar Challenger from the Gulf of Mexico, Leg 10 [M.S. thesis.]. Texas A\&M University, College Station.

Trabant, P. K., Bryant, W. R., and Bouma, A. H., 1975. Consolidation characteristics of sediments from Leg 31 of the Deep Sea Drilling Project. In Karig, D. E., Ingle, J. C., Jr., et al., Init. Repts. DSDP, 31: Washington (U.S. Govt. Printing Office), 569-572.

Znidarcic, D., 1982. Laboratory determination of consolidation properties of cohesive soil [Ph.D. dissert.]. Univ. of Colorado, Boulder.

Znidarcic, D., and Schiffman, R. L., 1981. Finite strain consolidation: Test conditions. J. Geotech. Eng. Div. Am Soc. Civ. Eng., Proc. Pap. 16221), 107:684-688.

1982. "On Terzaghi's concept of consolidation." Geotechnique, 32:387-389.

\section{APPENDIX \\ List of Symbols}

$A \quad=$ Pore pressure parameter

$a_{y} \quad=$ Coefficient of consolidation

$C_{c}=$ Compression index

$c_{y} \quad=$ Coefficient of consolidation

$e \quad=$ Void ratio

$e_{o} \quad=$ Void ratio at effective overburden pressure

$e_{c} \quad=$ Void ratio at preconsolidation pressure

$G_{s} \quad=$ Specific gravity of solids

$h^{s}=$ Depth

$k=$ Coefficient of permeability

$k_{c}=$ Coefficient of permeability at preconsolidation pressure 
$k_{O}=$ Coefficient of permeability at effective overburden pressure

$L L=$ Liquid limit

$m_{v}=$ Coefficient of volume change

$n \quad=$ Porosity

$O C R=$ Overconsolidation ratio

$P I \quad=$ Plasticity index

$P L \quad=$ Plastic limit

$r \quad=$ Pore water salinity

$s_{u} \quad=$ Undrained shear strength

$t=$ Time

$u_{e} \quad=$ Excess pore pressure

$u_{u}=$ Excess pore pressure at the undrained boundary

$v=$ Deformation velocity

$w \quad=$ Water content $\bar{w} \quad=$ Corrected water content

$W_{w}=$ Weight of water

$W_{s}=$ Weight of solids

Q = Density

$\varrho_{d} \quad=$ Dry density

$\phi^{\prime}=$ Effective fraction angle

$\phi_{c u}^{\prime}=$ Friction angle in terms of total stresses

$\phi_{d}=$ Effective friction angle from direct shear test

$\sigma_{1} \quad=$ Major principal stress

$\sigma_{3}=$ Minor principal stress

$\sigma_{y}=$ Total vertical stress

$\sigma_{v}^{\prime} \quad=$ Effective vertical stress

$\sigma_{c}^{\prime} \quad=$ Preconsolidation pressure

$\sigma_{o}^{\prime} \quad=$ Effective vertical overburden stress

$\gamma_{w}=$ Unit weight of water 